\title{
The Permissible Scope of OSHA Complaint Inspections
}

To enforce its health and safety standards, the Occupational Safety and Health Administration ("OSHA") conducts nonconsensual inspections of worksites. The two predominant types of OSHA searches are programmed and complaint inspections. ${ }^{1}$ The former are routine, facility-by-facility inspections based on neutral plans; ${ }^{2}$ the latter are investigatory searches made in response to employee allegations of specific hazards. ${ }^{3}$ In Marshall v. Barlow's, Inc., ${ }^{4}$ the Supreme Court held that administrative warrants must be obtained for both types of inspections."

Programmed inspections typically extend throughout an employer's establishment. The Secretary of Labor ${ }^{6}$ has argued that

1 In addition, OSHA conducts investigations of imminent dangers, fatalities, and catastrophes, as well as follow-up inspections to ensure compliance with citations issued on the basis of prior inspections. See U.S. Dep'T of Labor, Field Operations Manual, ch. IV, reprinted in 1981 Occ. SAFETY \& HeALTH REP. FILE (BNA) 77:2301-11 [hereinafter cited without cross-reference as FIELd Manual]. These inspections are not addressed in the Occupational Safety and Health Act of 1970 ("Act"), 29 U.S.C. $\$ \S 651-678$ (1976). When imminent danger or fatality/catastrophe investigations are based on employee allegations, statutory limitations on the scope of complaint inspections, see part I infra, must be observed. See BP Oil, Inc. v. Marshall, 509 F. Supp. 802 (E.D. Pa. 1981) (upholding warrant for imminent danger inspection because of its limited scope). Even when based on information from other sources, such inspections are subject to the fourth amendment's limitations on the scope of complaint inspections because they are triggered by information of specific violations in a particular facility. See part II infra.

2 See text and notes at notes 16-18 infra. For a discussion of the criteria for a neutral plan, see text and notes at notes 74-76, 84 infra.

See text and notes at notes 19-32 infra.

436 U.S. 307 (1978).

- Id. at $325 \& \mathrm{n} .23$. On the nature of the administrative warrant, see text and notes at notes 52-76 infra.

- The Act created OSHA as an agency of the Department of Labor and gave the Secretary of Labor the power to inspect worksites. See 29 U.S.C. \$§ 657(a), (f). See also id. § 657(g)(2). The Act also created the Occupational Safety and Health Review Commission ("OSHRC"), an independent administrative tribunal within the Department of Labor. Id. \& 661. Though the warrants for OSHA inspections are issued by and primarily challenged in the federal district courts, OSHRC plays a growing role in determining the permissible scope of OSHA searches. See, e.g., Sarasota Concrete Co., 9 Occ. Safety \& Health Cas. (BNA) 1608 (OSHRC 1981). See also Baldwin Metals Co. v. Donovan, 9 Occ. Safety \& Health Cas. (BNA) 1569 (5th Cir. 1981) (requiring exhaustion of remedies before OSHRC for a fourth amendment claim). 
complaint inspections, though prompted by an employee's specific complaint, similarly may encompass the employer's entire premises. ${ }^{7}$ Employers have countered that the scope of complaint inspections is limited both by the terms of the Occupational Safety and Health Act of 1970 ("Act") ${ }^{8}$ and by the fourth amendment. The district courts are divided over the permissible scope of these searches, ${ }^{10}$ and only two courts of appeals have addressed the issue

7 The Secretary's regulations are explicit: "Inspections under this section shall not be limited to matters referred to in the complaint." 29 C.F.R. § 1903.11(b) (1981). See also Field Manual, ch. VI, § D.4, reprinted in 1979 Occ. SafeTy \& Health Ref. File (BNA) 77:2701 ("Normally, if time and resources permit, the inspection should cover not only violations and dangers alleged in the complaint, but the entire establishment of the employer."). The manual was modified in 1981 to restrict wall-to-wall searches to high-hazard industries. Id. § H.1, reprinted in 1981 Occ. SAFETY \& Health Ref. Fne (BNA) 77:2703.

The expansiveness of the Secretary's position is illustrated in Whittaker Corp. v. OSHA, 6 Occ. Safety \& Health Cas. (BNA) 1495 (M.D. Pa. 1978), appeal dismissed, 594 F.2d 855 (3d Cir. 1979). On a showing of probable cause to inspect the condition of the crane at the "No. 69 [armor plate] building at the Berwick facility," id. at 1495, OSHA sought a warrant of such breadth that it "would have permitted inspection of both the Berwick and Renovo facilities and every conceivable condition therein, including files . . . "Id.

Some courts have accepted the Secretary's position out of deference to agency interpretation. E.g., Burkart Randall Div. of Textron, Inc. v. Marshall, 625 F.2d 1313, 1326 (7th Cir. 1980) (Sprecher, J.). The Secretary's interpretation cannot be determinative, however, where he seeks to extend his inspection authority beyond the limits laid down in the Act. See Marshall v. North Am. Car Co., 626 F.2d 320, 323-24 (3d Cir. 1980).

829 U.S.C. $\S \S 651-678$ (1976). The full title of the Act is the Williams-Steiger Occupational Safety \& Health Act of 1970.

$\checkmark$ U.S. Const. amend. IV. See note 52 infra.

${ }^{10}$ Several courts have accepted the Secretary's position that scope limitations are a superfluous protection for the employer and an unjustified burden on OSHA. See In re Marsan Co., 7 Occ. Safety \& Health Cas. (BNA) 1557 (N.D. Ind. 1979); In re Wisconsin Steel, No. 79-C-4284 (N.D. Ill. Dec. 28, 1979) (mem. op.), cited in Burkart Randall Div. of Textron, Inc. v. Marshall, 625 F.2d 1313, 1324 (7th Cir. 1980); In re Chicago Magnet Wire Corp., 5 Occ. Safety \& Health Cas. (BNA) 2024 (N.D. Ill. 1977); In re Gilbert \& Bennett Mfg. Co., 5 Occ. Safety \& Health Cas. (BNA) 1375 (N.D. Ill. 1977), aff'd on other grounds, 589 F.2d 1335 (7th Cir. 1979).

Most district courts, however, have read the fourth amendment to require that warrants be limited in scope to the subject matter of the complaint. See In re ASARCO, Inc., $508 \mathrm{~F}$. Supp. 350 (N.D. Tex. 1981); Marshall v. North Am. Car Co., 476 F. Supp. 698 (M.D. Pa. 1979), aff'd, 626 F.2d 320 (3d Cir. 1980); In re Central Mine Equip. Co., 7 Occ. Safety \& Health Cas. (BNA) 1185 (E.D. Mo.), vacated on other grounds sub nom. Marshall v. Central Mine Equip. Co., 608 F.2d 719 (8th Cir. 1979); Whittaker Corp. v. OSHA, 6 Occ. Safety \& Health Cas. (BNA) 1492 (M.D. Pa.) (warrant denied), reconsidered, 6 Occ. Safety \& Health Cas. (BNA) 1495 (M.D. Pa. 1978) (restricted warrant granted), appeal dismissed, 594 F.2d 855 (3d Cir. 1979). The OSHRC recently reached the same conclusion in Sarasota Concrete Co., 9 Occ. Safety \& Health Cas. (BNA) 1608, 1617 (OSHRC 1981). For dicta to the same effect, see West Point-Pepperell, Inc. v. Marshall, 496 F. Supp. 1178, 1186-87 (N.D. Ga. 1980); Marshall v. Consolidated Rail Corp., 7 Occ. Safety \& Health Cas. (BNA) 2015, 2018 (W.D. Pa. 1979), appeal dismissed for lack of jurisdiction, 631 F.2d 1122 (3d Cir. 1980); Marshall v. Berwick Forge \& Fabricating Co., 474 F. Supp. 104 (M.D. Pa. 1979). Cf. Mar- 
directly. ${ }^{11}$ In Burkart Randall Division of Textron, Inc. v. Marshall, ${ }^{12}$ a divided panel of the Seventh Circuit upheld a "wall-towall" search warrant that was obtained on the basis of limited employee complaints. ${ }^{13}$ The Third Circuit took the opposite stance in Marshall v. North American Car Co., ${ }^{14}$ reading the Act to require

shall v. Wollaston Alloys, Inc., 479 F. Supp. 1102, 1104 (D. Mass. 1979) (restrictions on the scope of an administrative warrant must be tailored to match the probable cause on which the warrant is based); Marshall v. Pool Offshore Co., 467 F. Supp. 978 (W.D. La. 1979) (probable cause to inspect one employer cannot justify inspection of other employers at worksite).

Other courts have relied on section 8(f) of the Act, 29 U.S.C. $§ 657(f)$ (1976), to limit the scope of complaint inspections. See BP Oil, Inc. v. Marshall, 509 F. Supp. 802 (E.D. Pa. 1981); Marshall v. Trinity Indus., Inc., 7 Occ. Safety \& Health Cas. (BNA) 1851 (W.D. Okla. 1979).

${ }^{11}$ The issue was touched on in several other circuit cases. It was raised by counsel on appeal in In re Gilbert \& Bennett Mfg. Co., 589 F.2d 1335 (7th Cir. 1979), leading Judge Sprecher in Burkart Randall Div. of Textron, Inc. v. Marshall, 625 F.2d 1313, 1324-25 n.18 (7th Cir. 1980), to argue that by affirming the district court's decision, the Seventh Circuit rejected limitations on scope. The Ninth Circuit upheld the issuance of a wall-to-wall warrant despite objections to its scope in J.R. Simplot Co. v. OSHA, 640 F.2d 1134 (9th Cir. 1981), petition for cert. filed, 50 U.S.L.W. 3404 (U.S. Sept. 21, 1981) (81-863). Cf. Marshall v. Horn Seed Co., 647 F.2d 96 (10th Cir. 1981) (quashing wall-to-wall complaint warrant for lack of probable cause).

The Eighth Circuit termed the Secretary's argument "a tenuous one" in Marshall v. Central Mine Equip. Co., 608 F.2d 719, 720 n.1 (8th Cir. 1979) (expressly declining to reach the merits). The Tenth Circuit rejected a challenge to scope, finding the warrant at issue sufficiently limited, in Marshall v. W\&W Steel Co., 604 F.2d 1322 (10th Cir. 1979). Limitations on the scope of inspections under the Federal Coal Mine Safety \& Health Act, 30 U.S.C. $\S \S 801-960$ (1976), were held to be constitutionally required by the Sixth Circuit in United States v. Consolidation Coal Co., 560 F.2d 214, 222 (6th Cir. 1977), vacated, 436 U.S. 942, reinstated, 579 F.2d 1011 (6th Cir. 1978), cert. denied, 439 U.S. 1069 (1979).

12625 F.2d 1313 (7th Cir. 1980).

1s Anonymous complaints had alleged inadequate fire escapes and unsanitary conditions in the press department, eating areas, and rest rooms. Id. at $1315 \mathrm{n} .1$; see Brief for Appellant at 2, Burkart Randall Div. of Textron, Inc. v. Marshall, 625 F.2d 1313 (7th Cir. 1980). Writing for the court, Judge Sprecher held that "the inspection need not be limited in scope to the substance of [the] complaints." Id. at 1325. Chief Judge Fairchild declined to join Judge Sprecher's opinion but voted to uphold the warrant, claiming, without any apparent factual support, that the hazards alleged were "sufficiently diffuse to sustain the magistrate's determination that a search of the entire workplace was reasonable." Id. at 1326. Judge Wood in dissent argued that the warrant contravened the fourth amendment by authorizing inspection of areas "for which there was no showing of any likelihood that violations existed ...."Id. at 1327. The split on the panel has been interpreted by some courts as imposing limitations on the scope of complaint warrants. See, e.g., In re ASARCO, Inc., 508 F. Supp. 350, 352 (N.D. Tex. 1981) (Burkart Randall held "that the Fourth Amendment require[s] that the scope of a [complaint] warrant be tailored to the specific showing of probable cause"). The case cannot be read, however, as limiting the Secretary's power to search in any meaningful way.

${ }^{14} 626$ F.2d 320 (3d Cir. 1980), aff'g 476 F. Supp. 698 (M.D. Pa. 1979). Three complaints were made about the 70-acre facility: spark danger in the steam rack area; poor ventilation, spark danger, and a lack of safety lines in one of the paint shops; and an overloaded crane in 
that "the scope of the inspection . . . bear an appropriate relationship to the violations alleged in the complaint."15

This comment argues that warrants for complaint inspections may authorize investigation only of employees' specific complaints. The language and structure of the Act so restricts OSHA's investigatory powers. Moreover, the fourth amendment requires a greater showing of probability that a violation exists for complaint inspections than for neutral programmed inspections; complaint searches therefore must be confined to those areas for which employee complaints provide this higher level of probability.

\section{Statutory Limits on Scope}

The Secretary of Labor derives his authority to inspect worksites from section 8 of the Act. ${ }^{16}$ Programmed inspections are authorized by the "extremely general"17 section 8(a), which provides for entry into "any . . . workplace or environment where work is performed by an employee of an employer."18 These inspections

the steel yard. Id. at $321 \&$ n.1. The company offered to admit the OSHA compliance officers without a warrant if they confined their search to the areas complained of. Instead, the inspectors returned with a wall-to-wall warrant.

[They] did not inspect those areas set forth in the complaint and evidenced no intention of inspecting the same with any immediacy but rather inspected whatever portions of the plant they desired to inspect even after being informed by North American Car officials that their inspections would not be permitted after a certain date.

476 F. Supp. at 707. After several days of inspection, the company refused to permit the compliance officers to reenter. OSHA sought to have North American found in contempt, filing citations that called for penalties of $\$ 36,500$ for violations observed in areas not complained of. Supplemental Brief for Appellee at 7, Marshall v. North Am. Car. Co., 626 F.2d 320 (3d Cir. 1980).

${ }^{15} 626 \mathrm{~F} .2 \mathrm{~d}$ at 324 . The district court found the warrant to be unconstitutionally overbroad. 476 F. Supp. at 706. The Third Circuit did not reach the constitutional issue, affirming instead on statutory grounds. 626 F.2d at 323. Because the Secretary's argument on appeal was that "a wall-to-wall search is permissible in any case where OSHA has received an employee complaint," id. at 322 (emphasis in original), the court did not "decide the exact relationship that must exist" between the allegations in the complaint and the scope of the search warrant, $i d$. at 324 .

1629 U.S.C. § 657 (1976).

17 Rothstein, OSHA Inspections after Marshall v. Barlow's, Inc., 1979 Duke L.J. 63, 83.

1s 29 U.S.C. $\$ 657$ (a) (1976). This section authorizes representatives of the Secretary of Labor

(1) to enter without delay and at reasonable times any factory, plant, establishment, construction site, or other area, workplace or environment where work is performed by an employee of an employer; and

(2) to inspect and investigate during regular working hours and at other reasonable times, and within reasonable limits and in a reasonable manner, any such place of employment and all pertinent conditions, structures, machines, apparatus, devices, equipment, and materials therein, and to question privately any such employer, owner, 
typically extend throughout an employer's premises. The more narrow section 8(f) addresses complaint inspections. Under that section, an employee who believes that a violation or danger exists may notify the Secretary, who then conducts a "special inspection . . . to determine if such violation or danger exists."19

\section{A. The Limited Scope of Section 8(f)}

If Congress had intended employee complaints to prompt thoroughgoing section 8(a) inspections, it need only have provided that upon receipt of a complaint, the Secretary would make an inspection. Yet section 8(f) labels the complaint inspection a "special inspection," ${ }^{20}$ suggesting that such searches have a distinct character. ${ }^{21}$ The thrice-repeated phrase "such violation or danger" in section $8(f)^{22}$ indicates that the Secretary may do no more than "conduct an inspection of the condition" alleged by the employee. ${ }^{23}$ Nothing in section 8(f) either invites or authorizes the Secretary to determine if other, unmentioned violations can be found on the premises. $^{24}$ The complaint procedure is designed to determine the existence vel non of a particular hazard, and the Secretary may go

operator, agent or employee.

The scope of a section 8(a) inspection is not as unlimited as this language suggests. See note 34 infra.

1029 U.S.C. $\$ 657(f)$ (1976). The section provides that:

(1) Any employees or representative of employees. who believe that a violation of a safety or health standard exists that threatens physical harm, or that an imminent danger exists, may request an inspection by giving notice to the Secretary or his authorized representative of such violation or danger . . . . If upon receipt of such notification the Secretary determines there are reasonable grounds to believe that such violation or danger exists, he shall make a special inspection in accordance with the provisions of this section as soon as practicable, to determine if such violation or danger exists.

2029 U.S.C. \& 657(f)(1) (1976).

21 To deny that "special" restricts the scope of complaint warrants, as does Burkart Randall Div. of Textron, Inc. v. Marshall, 625 F.2d 1313, 1326 (7th Cir. 1980) (Sprecher, J.), is to ignore the legislative mandate not to "convert every $\$ 8(f)$ inspection into a $\$ 8(a)$ wallto-wall inspection." Marshall v. North Am. Car Co., 626 F.2d 320, 323 (3d Cir. 1980) (a special inspection is one limited to investigation of the violation alleged in the complaint). See also Marshall v. Trinity Indus., Inc., 7 Occ. Safety \& Health Cas. (BNA) 1851, 1854 (W.D. Okla. 1979).

${ }^{22}$ See note 19 supra.

23116 Cong. Rec. 37,629 (1970) (remarks of Sen. Cranston).

24 A complaint intended to give notice of one violation may inadvertently provide notice of another. A violation, however, may be investigated only if the complaint adequately describes it and supplies the Secretary with reasonable grounds to believe it exists. See 29 U.S.C. § 657(f)(1) (1976). 


\section{no further than necessary to make that determination. ${ }^{25}$}

The legislative history of section. 8(f) supports this narrow reading. Congress did not create the complaint inspection procedure without concern for its abuse. ${ }^{26}$ Members recognized the potential for false and malicious complaints and made clear their intention that the Secretary "not permit this procedure to be used as an harassment device."27 The debates were rife with expressions of distrust of inspectors' judgments in the field. ${ }^{28}$ Numerous safeguards were built into the statute to avoid groundless complaint inspections. ${ }^{28}$ Conscious of the disruptions caused by OSHA in-

${ }^{25}$ Marshall v. North Am. Car Co., 626 F.2d 320, 323 (3d Cir. 1980); BP Oil, Inc. v. Marshall, 509 F. Supp. 802, 808 (E.D. Pa. 1981); Marshall v. Trinity Indus., Inc., 7 Occ. Safety \& Health Cas. (BNA) 1851, 1854 (W.D. Okla. 1979). See also In re ASARCO, Inc., 508 F. Supp. 350, 352-53 (N.D. Tex. 1981).

${ }^{28}$ Concern that section 8(f) "opens the door for . . . a good deal of harassment," 116 CoNG. REc. 36,536 (1970) (remarks of Sen. Dominick); id. at 36,523, 36,536 (remarks of Sens. Dominick and Saxbe), led the bill's sponsor to reassure his colleagues that section 8(f) guards "against frivolous complaints," id. at 37,340 (remarks of Sen. Williams). Experience under the Act has shown that this concern was well founded. See text and note at note 104 infra.

${ }^{22} 116$ CoNG. REc. 42,207 (1970) (remarks of Rep. Steiger).

28 The sponsors twice altered the proposed legislation to meet "the concern expressed by some that [major questions] should not be within the sole judgment of a single inspector." S. REP. No. 1282, 91st Cong., 2d Sess. 13, reprinted in 1970 U.S. Code Cong. \& AD. NEws 5177, 5189-90. The legislators first restricted, see id., and then removed altogether, see 29 U.S.C. $\$ 662$ (a) (1976), the power of inspectors to close down plants without a court order. They also redefined the hazards that could be cited by the inspector under the General Duty Clause, 29 U.S.C. § 654(a)(1) (1976). See 116 Cong. REc. 42,203 (1970) (remarks of Rep. Daniels) (House conferees "cognizant of the concern of [their colleagues] over arbitrary action by inspectors"). The coauthor of the House bill criticized another proposal as "giv[ing] the inspectors dictatorial powers," id. at 38,704 (remarks of Rep. Sikes), commenting that "we have human frailties in all walks of life. This includes inspectors who would be employed in this program," id. See also id. at 38,382 (remarks of Rep. Erlenborn) (concern about "subjective judgment" of inspectors); id. at 38,386 (remarks of Rep. Dent) (fearing "injudicious decision by some inspector who reads the letter of the law and does not have brains enough to interpret it"); id. at 38,393 (remarks of Rep. Michel) (proposed bill puts "unreasonable power and authority in the hands of inspectors, many of whom might be incompetent or easily influenced"); $i d$. at 38,377-78 (remarks of Rep. Daniels); id. at 38,702 (remarks of Rep. Steiger) (care taken to avoid giving inspectors excessive powers). These concerns were prophetic. See note 106 infra.

29 Section $8(f)(1)$ requires that the complaint be from an "employee or representative of employees," be in writing and signed, and set forth with "reasonable particularity" either a violation of a standard threatening "significant" physical harm, see 116 CoNG. REc. 42,207 (1970) (remarks of Rep. Steiger), or an imminent danger. The employee must have a "good faith" belief that the alleged violation or danger exists, see id., and the Secretary must find "reasonable grounds" to believe that the alleged violation or danger exists, see S. REP. No. 1282, 91st Cong., 2d Sess. 59, reprinted in 1970 U.S. Code Cong. \& AD. News 5177, 5224 (individual views of Sen. Javits) (reasonable grounds requirement added to "ensure that inspections are not required in response to groundless complaints"). 
spections, ${ }^{30}$ Congress required that inspections be carried out "with a minimum burden upon employers." best met by restricting complaint inspections to investigation of the specific violations alleged. ${ }^{32}$

\section{B. The Relevance of Section 8(a)}

The Secretary of Labor has attempted to circumvent the restrictions on scope of section 8(f) by asserting that the broad language of section $8(a)^{33}$ defines the extent of his authority to conduct not only programmed inspections, but complaint inspections as well. ${ }^{34}$ According to the Secretary, the clause in section 8(f) that

so Even absent official or employee abuse, the burdens placed on employers by OSHA searches are considerable:

Inspections of entire plants-referred to as "wall to wall" in agency jargon-frequently extend over several weeks. They necessarily create inconvenience to the employer and a certain amount of lost time for employees who escort the inspector or are otherwise disrupted in their work. Even if no violations were found and no citations issued, an employer would not regard such an inspection as benign.

Cerro Metal Prods. v. Marshall, 620 F.2d 964, 974 (3d Cir. 1980) (footnotes omitted) (sixweek inspection); see also In re ASARCO, Inc., 508 F. Supp. 350, 353-54 (N.D. Tex. 1981) (limited inspection estimated to require six weeks); In re CF\&I Steel Corp., 489 F. Supp. 1302,1305 (D. Colo. 1980) (OSHA sought a "20-man 60-day warrant"). The length and intensity of OSHA inspections have increased substantially as the agency has sought "to assure thorough inspections." Whiting, OSHA's Enforcement Policy, 31 LAB. L.J. 259, 262 (1980).

3129 U.S.C. \& 657(d) (1976).

32 It has been argued, however, that allowing wall-to-wall inspections in response to specific complaints reflects the spirit of the Act. See Burkart Randall Div. of Textron, Inc. v. Marshall, 625 F.2d 1313, 1325 (7th Cir. 1980) (Sprecher, J.); In re Gilbert \& Bennett Mfg. Co., 5 Occ. Safety \& Health Cas. (BNA) 1375, 1375 (N.D. Ill. 1977), aff'd on other grounds, 589 F.2d 1335 (7th Cir. 1979). See also In re Chicago Magnet Wire Corp., 5 Occ. Safety \& Health Cas. (BNA) 2024, 2024-25 (N.D. Ill. 1977). The legislative history, demonstrating concern for excessive zeal and spurious complaints, refutes such an interpretation. See text and notes at notes 26-31 supra, 41-47 infra.

s3 See note 18 supra.

34 Even this section imposes limits on the scope of OSHA investigations, however. Although it has been carelessly claimed that the section "authorizes an inspection of the employer's entire workplace," Burkart Randall Div. of Textron, Inc. v. Marshall, 625 F.2d 1313, 1326 (7th Cir. 1980) (Sprecher, J.), section 8(a)(2) confines the scope of investigations "within reasonable limits and in a reasonable manner" to "pertinent conditions, structures, machines, apparatus, devices, equipment, and materials . . ." 29 U.S.C. \& 657(a)(2) (1976). The conditions "pertinent" to a search and the areas within its "reasonable" limits vary with the purpose of the search. For example, a woodworking shop located in the same facility as a foundry is not pertinent to or within the reasonable limits of a programmed foundry inspection. See 29 C.F.R. $\$ 1903.2(b)$ (1981) ("[w] here distinctly separate activities are performed at a single physical location . . . each activity shall be treated as a separate physical establishment"). Therefore, even if complaint inspections are limited in scope only by section $8(a)(2)$, the Secretary exceeds the limits of his inspection authority if he ignores the purpose for entry-investigation of the complaint-by extending his search to areas not 
requires complaint inspections to be carried out "in accordance with the provisions of this section"3s refers to the expansive scope of section $8(\mathrm{a})(2) .^{36} \mathrm{It}$ would be odd, however, if this cross-reference was intended to override the explicit limits on scope set forth in section 8(f) itself. The sounder construction is to read the "in accordance with" language as supplementing rather than superseding the requirements of section 8(f). Other provisions in section 8 undeniably regulate the numerous aspects of inspections on which section $8(\mathrm{f})$ is silent. ${ }^{37}$ Complaint inspections must be "in accordance with" these provisions, but they also must be faithful to the "such violation or danger" restriction imposed by section $8(f)$.

The Secretary has argued that section 8(a) nevertheless governs complaint inspections because it contains the Act's sole grant of inspection authority. ${ }^{38}$ Under this interpretation, section $8(f)$ merely adds a duty to exercise that authority on receipt of a valid employee complaint: section $8(f)$ defines only what the Secretary must do, while section 8(a) defines what he may do, in responding to employee complaints. ${ }^{3 \theta}$

pertinent to that purpose.

ss 29 U.S.C. § 657(f)(1) (1976).

36 Reply Brief for the Secretary of Labor at 4-5, Marshall v. North Am. Car Co., 626 F.2d 320 (3d Cir. 1980). This view was adopted in Burkart Randall Div. of Textron, Inc. v. Marshall, 625 F.2d 1313, 1326 (7th Cir. 1980) (Sprecher, J.) ("The only part of section 8 which arguably pertains to the scope of inspection is section 8(a)(2)."). See also Marshall v. Daniel Constr. Co., 563 F.2d 707, 710 (5th Cir. 1977) (dicta), cert. denied, 439 U.S. 880 (1978).

${ }^{37}$ For example, the inspector may investigate only places of employment, 29 U.S.C. § 657(a) (1976), must present his credentials, $i d$. $\$ 657(\mathrm{a})(1)$, may inspect only at reasonable times and in a reasonable manner, $i d . \S 657(\mathrm{a})(2)$, and must obtain information with a minimum burden on the employer, id. §657(d). He may conduct interviews, id. § 657(a)(2), and subpoena witnesses, id. $\S 657(\mathrm{~b})$. Representatives of both the employer and employees may accompany the inspector. Id. § 657(e).

${ }_{38}$ See Burkart Randall Div. of Textron, Inc. v. Marshall, 625 F.2d 1313, 1321, 1326 (7th Cir. 1980) (Sprecher, J.); Aluminum Coil Anodizing Corp., 1 Occ. Safety \& Health Cas. (BNA) 1508, 1510 (OSHRC 1974) (Cleary, Comm'r, concurring). There is language in the legislative history that arguably supports this position. A substitute bill contained only one inspection provision, identical to section 8(a). A supporter assured the Senate that "it is contemplated that the Secretary would, of course, give full consideration to employee complaints of safety and health violations, and he would conduct necessary inspections." 116 ConG. REc. 35,608 (1970) (statement of Sen. Saxbe). See id. at 37,327 (introduction of the substitute bill).

39 See Marshall v. Horn Seed Co., 647 F.2d 96, 100 n.3 (10th Cir. 1981). Similarly, OSHRC has relied on section 8 (a) to uphold complaint inspections based on complaints from nonemployee sources, despite the failure of such searches to meet the requirements set forth in section 8(f). See, e.g., Hydraform Prods. Corp., 7 Occ. Safety \& Health Cas. (BNA) 1995, 1996 (OSHRC 1979); Millcon Corp., 7 Occ. Safety \& Health Cas. (BNA) 1926, 1927 (OSHRC 1979); Aluminum Coil Anodizing Corp., 5 Occ. Safety \& Health Cas. (BNA) 1381, 
This effort to transform section 8(a) into a license to conduct wall-to-wall inspections in response to specific section 8(f) complaints is unconvincing. Whatever the source of the Secretary's inspection authority, section 8(f) inescapably limits it in the complaint context..$^{40}$ Moreover, the structure and legislative history of the section do not support the duty/authority distinction advanced by the Secretary, demonstrating instead that section $8(\mathrm{f})$ creates an independent investigatory mechanism whose goals are distinct from those of the general inspection program embodied in section 8(a).

The Act's sponsors, concerned that employees be protected from imminent threats to safety, originally included a provision allowing employees to refuse to work around toxic substances. ${ }^{41}$ Branded a "strike with pay" provision, the proposal was dropped by the Senate committee in favor of a general employee complaint provision. ${ }^{42}$ Proponents asserted that the complaint inspection pro-

1382 (OSHRC 1977); Aluminum Coil Anodizing Corp., 1 Occ. Safety \& Health Cas. (BNA) 1508 (OSHRC 1974). See also OSHA INSTRUCTION CPL 2.12A, § D, reprinted in 1979 Occ. SAFETY \& HzALTH REP. Fine (BNA) 21:8177, :8177 (OSHA "shall conduct a thorough evaluation of all complaints regardless of the complaint's formality; i.e., whether or not filed in writing by an employee or his representative."). The method of analysis in these cases belies their suggestion that section $8(f)$ is not a source of authority, for it is only after finding that the searches do not come within the ambit of section $8(f)$ that the OSHRC turns to section 8(a).

Only one court has permitted an inspection based on a complaint from a source other than an employee or employee representative, and it restricted the inspection according to the limitations imposed by section 8(f). In re Central Mine Equip. Co., 7 Occ. Safety \& Health Cas. (BNA) 1185, 1188-89 (E.D. Mo.), vacated on other grounds sub nom. Marshall v. Central Mine Equip. Co., 608 F.2d 719 (8th Cir. 1979). See also In re Metal Bank of Am., Inc., 9 Occ. Safety \& Health Cas. (BNA) 1972 (E.D. Pa. 1981) (limiting the scope of a search based on an informal complaint). Similarly, warrants based on specific noncomplaint evidence have been issued only where the evidence gave probable cause to believe the hazards existed. E.g., In re Federal Clearing Die Casting Co., 484 F. Supp. 215, 216 (N.D. Ill. 1980) (inspection triggered by press account), rev'd on other grounds sub nom. Donovan v. Federal Clearing Die Casting Co., 655 F.2d 793 (7th Cir. 1981).

40 See text and notes at notes 20-32, 34 supra.

11 H.R. 16,785, 91st Cong., 2d Sess. § 19(a)(5) (1970), reprinted in SzN. Comm. ON LAB. \& Pub. Wrlfare, 92d Cong., 1st Sess., Legislative History of the Occupationaz Sarety AND Health ACT OF 1970, at 893, 969-70 (1971). See Whirlpool Corp. v. Marshall, 445 U.S. 1, 14-16 (1980).

42 See 116 Cong. Rrc. 37,326 (1970) (remarks of Sen. Williams). This provision became the present section $8(f)(1)$ after an amendment added the requirement that the Secretary have reasonable grounds to believe the complaint. S. REP. No. 1282, 91st Cong., 2d Sess. 59, reprinted in 1970 U.S. CoDs CoNG. \& AD. NEws 5177, 5224 (views of Sen. Javits). Offered as an amendment in the House, see 116 Cong Rec. 38,377 (1970) (remarks of Rep. Daniels), the provision was tabled but accepted in conference. H. RaP. No. 1765, 91st Cong., 2d Sess. 37-38, reprinted in 1970 U.S. Code CoNG. \& AD. Naws 5228, 5234. 
vision "strengthened ... enforcement"4s and "enhance[d] the prospects [for] compliance."

These claims would not have been worth raising if, as the Secretary asserts, section 8(a) already had given the Secretary power to act on employee complaints. Although some increased compliance might result solely from the imposition of a duty on the Secretary, ${ }^{45}$ it is the information generated by this complaint mechanism that provides the truly substantial boost to enforcement of the Act. ${ }^{46}$ Thus, Congress envisioned section 8(f) as a special inspection mechanism that "enables employees subject to a risk of harm to get the Secretary into the situation quickly."

The Secretary's reading also is incompatible with the interpretation given section 8 by the Supreme Court. In Marshall v. Barlow's, Inc., ${ }^{48}$ the Court construed section 8(a) as authorizing rou-

43 116 Cong. REc. 38,378 (1970) (remarks of Rep. Daniels).

44 Id. at 37,326 (remarks of Sen. Williams).

4 Proponents of the Act took note of "over 30 years of utterly dismal performance by the Department of Labor of its safety and health responsibilities under the Walsh-Healey Act," 41 U.S.C. $\$ \S 35-45$ (1976), which applied to government contractors. S. REP. No. 2382, 91st Cong., 2d Sess. 55, reprinted in 1970 U.S. Code CoNG. \& AD. NEws 5177, 5219 (remarks of Sen. Javits). That Act was said to have failed because inspectors were derelict and colluded with employers. See also id. at 10, reprinted in 1970 U.S. Code Cong. \& AD. News at 5187 (necessity of employee involvement).

${ }^{18}$ It is impossible to enforce the Act simply through routine inspections. The Act applies to any employer "engaged in a business affecting commerce who has employees," 29 U.S.C. $§ 652(5)$ (1976), an estimated six million workplaces. Barlow's, Inc., v. Usery, 424 F. Supp. 437, 440 (D. Idaho 1976), aff'd sub nom. Marshall v. Barlow's, Inc., 436 U.S. 307 (1978). Even when programmed inspections are restricted to high-hazard facilities, OSHA resources only allow for inspection once every 10 years; the average general business establishment can be visited only once every 77 years. See Comment, OSHA v. The Fourth Amendment: Should Search Warrants Be Required for "Spot Check" Inspections?, 29 BAYLOR L. REv. 283, 301 (1977). Employees themselves are the best source of information about likely violators. As Senator Williams said in reference to the "walk-around" provision, 29 U.S.C. $\S 657$ (e) (1976): "Certainly no one knows better than the workingman what the conditions are, where the failures are, where the hazards are, and particularly where there are safety hazards." 116 CoNG. REc. 37,340 (1970). Section 8(f) in effect creates an army of unpaid inspectors whose complaints can focus inspection efforts efficiently and whose presence deters violations of the Act by employers.

47116 CoNg. REc. 38,378 (1970) (remarks of Rep. Daniels). See also id. at 36,536 (remarks of Sen. Saxbe):

On the face of it, it looks like this is a very good provision because it gives the man an opportunity to identify a safety hazard and to know that there will be a response, because it is also required that if they feel that imminent danger is present, they have to make this inspection.

(emphasis added). A literal reading of the section indicates that it provides a separate inspection mechanism. Donovan v. Burlington Northern, Inc., 10 Occ. Safety \& Health Cas. (BNA) 1175, 1178 (D. Mont. 1981).

48436 U.S. 307 (1978). 
tine inspections for which wall-to-wall search warrants may be issued on a "showing that specified businesses had been chosen ... on the basis of a general administrative plan . . . derived from neutral sources." of these characteristics; rather, as the Court noted in dicta, they are based on "specific evidence of an existing violation." It is not surprising that lower courts applying this construction have rejected the Secretary's attempts to characterize complaint inspections as neutral section 8 (a) searches. ${ }^{51}$ The plain words of the Act, its legislative history, and the weight of judicial construction all support the conclusion that section $8(f)$ alone defines the Secretary's authority to carry out complaint inspections, confining such searches to investigation of the violations or dangers alleged by the employee.

\section{Constitutional Limits on Scope}

The scope of an OSHA complaint inspection is also limited by the fourth amendment. ${ }^{32}$ In the criminal context, the amendment requires warrants to be confined in scope to the showing of probable cause: In extending the fourth amendment's protections to rou-

40 Id. at 321. For a discussion of what constitutes a neutral source, see text and notes at notes 74-76 infra.

so Id. at 321. See In re Urick Property, 472 F. Supp. 1193, 1194 (W.D. Pa. 1979) (Barlow's set forth a "double standard" for the scope of inspections under sections $8(a)$ and 8(f)).

In Whirlpool Corp. v. Marshall, 445 U.S. 1 (1980), the Supreme Court held that the deletion of the "strike-with-pay" provision, see text and notes at notes 41-42 supra, did not deprive employees of the right to absent themselves from hazardous worksites without pay. In finding that such an implicit right "conforms to the fundamental objective of the Act," id. at 11, the Court described section 8(f)(1) as an "express mechanism for protecting workers" that gives them "the right to inform OSHA of an imminently dangerous workplace condition or practice and request that OSHA inspect that condition or practice," id. at 8-9. This language reinforces the view that section $8(f)$ is an independent inspection mechanism.

s2 See, e.g., In re Northwest Airlines, 587 F.2d 12, 15 (7th Cir. 1978); In re CF\&I Steel Corp., 489 F. Supp. 1302, 1304 (D. Colo. 1980); In re Urick Property, 472 F. Supp. 1193, 1195 (W.D. Pa. 1979); Marshall v. Trinity Indus., Inc., 7 Occ. Safety \& Health Cas. (BNA) 1851, 1854 (W.D. Okla. 1979); Weyerhaeuser Co. v. Marshall, 452 F. Supp. 1375, 1379 (E.D. Wis. 1978), aff'd, 592 F.2d 373 (7th Cir. 1979); Sarasota Concrete Co., 9 Occ. Safety \& Health Cas. (BNA) 1608, 1615-16 (OSHRC 1981). The persistent failure of the Secretary to develop a neutral plan for investigation of employee complaints reinforces the fundamental differences between programmed and complaint inspections.

s2 U.S. ConsT, amend. IV:

The right of the people to be secure in their persons, houses, papers, and effects, against unreasonable searches and seizures, shall not be violated, and no Warrants shall issue, but upon probable cause, supported by Oath or affirmation, and particularly describing the place to be searched, and the persons or things to be seized. 
tine health and safety inspections, the Supreme Court created an "administrative warrant" that issues on less than traditional probable cause. ${ }^{\text {ss }}$ This warrant, which is required for all nonconsensual OSHA searches, ${ }^{54}$ is the product of the rebalancing of the opposing interests implicated by any official search. The breadth of routine programmed inspections is the result of the lower level of probability permitted by this rebalancing. The balance that permits wall-to-wall routine inspections cannot be extended, however, to the more intrusive complaint inspections, for which a higher level of probability, and therefore stricter limits on scope, are required.

\section{A. Traditional Probable Cause}

A primary purpose of the warrant requirement is that "those searches deemed necessary should be as limited as possible." "Bs Procedurally, this goal is achieved by requiring particular description of the object of the search ${ }^{86}$ and review by a magistrate. ${ }^{87}$ Substan-

ss See See v. City of Seattle, 387 U.S. 541, 542, 545-46 (1967); Camara v. Municipal Court, 387 U.S. 523, 538-39 (1967).

*4 Marshall v. Barlow's, Inc., 436 U.S. 307 (1978). This case arose from the 'refusal of the proprietor of a plumbing and electrical installation business to admit OSHA inspectors to conduct a programmed inspection unless they procured a warrant. Id. at 309-10.

There was little debate in Congress over whether the Act authorized warrantless searches. Compare 116 Cong. Rec. 38,709 (1970) (remarks of Rep. Steiger) ("[I]n carrying out inspection duties under this Act, the Secretary, of course, [has] to act in accordance with [the] applicable constitutional protections.") with H. REP. No. 1291, 91st Cong., 2d Sess. 55 (1970), reprinted in Sen. Comm. on Lab. \& Pub. Welfare, 92d Cong., Ist Sess., Legislative History of the Occupational Safety and Health Act of 1970, at 885 (1971) (minority views criticizing the Act's authorization of warrantless searches).

The Court in Barlow's found that both sections $8(a)$ and $8(f)$ purported to authorize, but did not require, warrantless searches. 436 U.S. at 309, 320 n.16. Because the Act was compatible with the engrafted warrant requirement, it was held to be constitutional. Id. at 321-22.

${ }^{35}$ Coolidge v. New Hampshire, 403 U.S. 443, 467 (1971).

so Particular description in the warrant application enables the magistrate to determine whether an item is likely to be found in the place alleged and to confine the search to those areas for which sufficient likelihood has been demonstrated. When incorporated in the warrant, the description limits the search by informing the searching officer and the person to be searched of the warrant's limits. See Marshall v. Wollaston Alloys, Inc., 479 F. Supp. 1102, 1104 (D. Mass. 1979). See generally Coolidge v. New Hampshire, 403 U.S. 443, 467 (1971) (particularity requirement included in the fourth amendment in response to Great Britain's use of "general warrants" that permitted "general, exploratory rummaging in a person's belongings"); LaFave, Administrative Searches and the Fourth Amendment: The Camara and See Cases, 1967 Sup. CT. REv. 1, 25.

${ }^{67}$ The permissible scope of a search is to be determined not by officers "engaged in the often competitive enterprise of ferreting out crime," but by "a neutral and detached magistrate." Aguilar v. Texas, 378 U.S. 108, 115 (1964) (quoting Johnson v. United States, 333 
tively, it is achieved by the probable cause requirement, which ensures that there exists "a substantial probability that the invasions involved in the search will be justified by discovery of offending items." 58 Because a search must be "strictly tied to and justified by" the exigencies underlying it, only those areas may be searched for which the necessary quantum of probable cause has been shown. ${ }^{59}$ For criminal searches, the required level of probability is high; ${ }^{60}$ this strict standard sharply limits in number and area the places for which a warrant may issue.

\section{B. Probable Cause in Administrative Searches}

In Camara v. Municipal Court ${ }^{81}$ and See v. City of Seattle, ${ }^{62}$ the Supreme Court imposed the warrant requirement on nonconsensual safety and health inspections. In doing so, the Court reversed the practice of two centuries and overturned a decision of but eight years. ${ }^{\text {ss }}$ At the same time, the Court redefined the level

U.S. 10, 14 (1948)). See Coolidge v. New Hampshire, 403 U.S. 443, 467 (1971) ("the magistrate's scrutiny is intended to eliminate altogether searches not based on probable cause"); Comment, Search and Seizure in the Supreme Court: Shadows on the Fourth Amendment, 28 U. CHI. L. Rev. 664, 690 (1961).

s8 Comment, supra note 57, at 687. See Brinegar v. United States, 338 U.S. 160, 175 (1949) ("In dealing with probable cause, . . . as the very name implies, we deal with probabilities.").

so Warden v. Hayden, 387 U.S. 294, 310 (1967) (Fortas, J., concurring); see Comment, supra note 57, at 687 (probable cause requires "substantial evidence . . . that the items will be found in the place to be searched") (footnote omitted).

${ }^{\circ 0}$ Probable cause in the criminal context requires that the government's agents have "facts and circumstances within their knowledge and of which they had reasonably trustworthy information. . . sufficient in themselves to warrant a man of reasonable caution in the belief" that evidence of an offense would be found in the place alleged. Carroll v. United States, 267 U.S. 132, 162 (1925). When an officer relies on information from a complainant, "the magistrate must be informed of some of the underlying circumstances from which . . . the officer concluded that the informant, whose identity need not be disclosed, . . . was 'credible' or his information 'reliable.' " Aguilar v. Texas, 378 U.S. 108, 114 (1964) (citation and footnote omitted). The reliability of the information must be scrutinized even where corroboration exists. Spinelli v. United States, 393 U.S. 410, 415 (1969).

-1 387 U.S. 523, 534 (1967). Camara involved an inspection of a rented building to determine if it was being used as a residence in violation of the housing code.

o2 387 U.S. 541, 545 (1967). See involved a routine fire code inspection of a commercial warehouse.

es Frank v. Maryland, 359 U.S. 360 (1959). In Frank, the Court upheld the imposition of a fine against a homeowner who had refused to admit a health inspector without a warrant, noting that warrantless health and regulatory inspections had continued unabated after the enactment of the Bill of Rights. Id. at 367-70. The Court restricted the warrant requirement to searches for evidence to be used in criminal prosecutions, reading the fourth amendment in light of the fifth amendment's protection against self-incrimination. When the search affected nothing more than "the right to be secure from intrusion into personal 


\section{of probable cause necessary to obtain such administrative warrants. ${ }^{64}$}

1. The Camara Balancing Test. Asserting that the "ultimate standard" of the fourth amendment is that of "unreasonable searches and seizures,"

privacy," id. at 365 , the Court required only that it be carried out in a way that minimized that intrusion, id. at 371-73. See also Boyd v. United States, 116 U.S. 616, 633-34 (1886).

The Court in Camara was concerned only marginally with the criminal penalty that might follow refusal to admit the inspectors, 387 U.S. at 527 n.2, emphasizing instead the civil sanctions for health and safety violations, $i d$. at 531. The Court's language was broad: "except in certain carefully defined classes of cases, a search of private property without proper consent is 'unreasonable' unless it has been authorized by a valid search warrant." Id. at 528-29. The Court thus purported to avoid the anomaly of having "the individual and his private property . . . fully protected by the Fourth Amendment only when the individual is suspected of criminal behavior." Id. at 530 \& n.6; see LaFave, supra note 56, at 18. The Court's later emphasis on the underlying sanction, however, see text and notes at notes 71-72 infra, reintroduced the tensions between the view of the fourth amendment as protector of personal privacy and the view of the amendment as a procedural right against selfincrimination that, like the fifth amendment, comes increasingly into play as the underlying sanction becomes more severe. See generally LaFave, supra note 56, at 17-20; McManis \& McManis, Structuring Administrative Inspections: Is there Any Warrant for a Search Warrant?, 26 AM. U.L. REv. 942, 963-65 (1977); Rothstein, supra note 17, at 66-67; Comment, supra note 57, at 692-98; Comment, Camara, See, and Their Progeny: Another Look at Administrative Inspections under the Fourth Amendment, 15 Colum. J.L. \& Soc. Pros. 61, 78-85 (1979).

64 Determining that a warrant is required "must be the beginning, not the end of our inquiry." Camara v. Municipal Court, 387 U.S. 523, 534 (1967). This further inquiry into the nature of probable cause was considered necessary because "the unique character of these inspection programs" raised "the question whether some other accommodation between public need and individual rights is essential." Id.

6s Id. at 539.

${ }^{68}$ U.S. CoNST. amend. IV; see note 52 supra. The relationship between the "unreasonable searches and seizures" clause and the "no Warrants shall issue" clause long has been a matter of dispute. Some have interpreted the clauses to mean that warrants are required to render searches reasonable. See, e.g., United States v. Matlock, 415 U.S. 164, 180 n.1 (1974) (Douglas, J., dissenting). Others have read them as creating two distinct constitutional protections: warrants for some searches, and reasonableness for all. See, e.g., Marshall v. Barlow's, Inc., 436 U.S. 307, 325-28 (1978) (Stevens, J., dissenting). On the general contours of this debate, see LaFave, supra note 56 , at 13 n.37; Comment, supra note 57, at 678-86.

Camara followed neither of these readings. Although it held that health and safety inspections are subject to the warrant clause, it did not find the meaning of reasonableness to be grounded in the traditional notions of probable cause embodied in the warrant clause. Instead, it held the reverse: that the content of the warrant clause is derived from the reasonableness clause. See 387 U.S. at 535 (probable cause exists when "a particular inspection is reasonable"). The textual and historical justifications for this construction are unclear. In so ruling, the Court employed the analysis of the case it overruled, Frank v. Maryland, 359 U.S. 360 (1959), which held that periodic inspections were governed only by the reasonableness clause. See See v. City of Seattle, 387 U.S. 541, 547-48 (1967) (Clark, J., dissenting). In Frank, Justice Frankfurter disputed the legitimacy of such a "synthetic search warrant," arguing that "[i]f a search warrant be constitutionally required, the requirement cannot be flexibly interpreted to dispense with the rigorous constitutional restrictions for its issue." 
sonableness of a search must be determined "by balancing the need to search against the invasion which the search entails." Probable cause was refashioned in terms of a "reasonable governmental interest": if "a valid public interest justifies the intrusion contemplated, then there is probable cause."18

Applying this test, the Court distinguished routine health and safety inspections from criminal searches. Although noting that such inspections can be as lengthy and physically intrusive as their criminal counterparts, ${ }^{\text {Bg }}$ the Court argued that administrative searches involve a "relatively limited invasion of the urban citizen's privacy.""o Because health inspections are "neither personal

\section{U.S. at 373.}

${ }^{67} 387$ U.S. at 537. One commentator has described the Camara balancing test in terms of the formula expounded by Judge Learned Hand in United States v. Carroll Towing Co., 159 F.2d 169, 173 (2d Cir. 1947): probable cause exists and a search is constitutional if $\mathrm{VP}>\mathrm{C}$, where $\mathrm{V}$ is the value to the government and society of the item sought, $\mathrm{P}$ the probability that the item will be found, and $C$ the cost of such official invasion to the persons searched. See Comment, supra note 63, at 78-85.

6s 387 U.S. at 539 (1967). The novelty of Camara was not in recognizing that "[t]he Framers struck . . . a balance" between the need to search and the right to be free from official intrusion. Fisher v. United States, 425 U.S. 391, 400 (1976). Probable cause long has been recognized as the Constitution's compromise between these opposing interests. $E . g$., Brinegar v. United States, 338 U.S. 160, 176 (1949). Camara's major departure from previous constitutional doctrine was in rebalancing, rather than relying on well-established standards of probable cause. See LaFave, supra note 56, at 12-13 \& n.38. Cf. Dunaway v. New York, 442 U.S. 200, 214 (1979) (refusing to reevaluate the quantum of probable cause for police station questionings because "the requisite 'balancing' has been performed in centuries of precedent").

By permitting searches on less than traditional probable cause, the Court thus gave its imprimatur to what until then had been unlawful: issuance on "loose, vague or doubtful bases of fact" of warrants authorizing "a general exploratory search in the hope that evidence of [violations] will be found," Go-Bart Importing Co. v. United States, 282 U.S. 344, 357-58 (1931). Thus the "overreaching" British Writs of Assistance that were "the immediate evil at which the Fourth Amendment was directed," Marshall v. Barlow's, Inc., 436 U.S. 307, 327-28 (1978) (Stevens, J., dissenting), have been reintroduced under the guise of constitutional protections.

387 U.S. at 530.

70 Id. at 537. The Court also suggested two other factors distinguishing the level of probability "reasonable" for health and safety inspections from that required for criminal searches. First, it pointed to the "long history of judicial and public acceptance" of health inspections. Id. at 537. Even if accurate, such a "history of acquiescence," Frank v. Maryland, 359 U.S. 360, 384 n.2 (1959) (Douglas, J., dissenting), should not justify a search without traditional probable cause any more than it justifies a search without a warrant. See LaFave, supra note 56, at 14 . Second, the Court asserted that "the public interest demands that all dangerous conditions be prevented or abated, yet it is doubtful that any other canvassing technique would achieve acceptable results." 387 U.S. at 537. This assertion lacks logical and empirical support; moreover, it cannot be justified constitutionally: "Like notions obtain by some law enforcement officials who take shortcuts in pursuit of criminals. The same pattern appears over and again whenever government seeks to use its compulsive 
in nature nor aimed at the discovery of evidence of crime," because inspectors do not enter suspecting a violation, the inspections are "less hostile" than criminal searches." Triggered by "neutral criteria" rather than human complaints, programmed inspections do not lend themselves to abuse by third parties, and they leave enforcement authorities unable to single out certain targets for repetitive or arbitrary searches. ${ }^{73}$ Because the risks of official and third-party abuse are less in the programmed inspection context, the Court found that a legitimate balance of reasonableness can be struck at a level of probability lower than that required for criminal warrants.

This level of probability is provided by a legislative or administrative inspection plan addressing industry-wide hazards and providing for selection of particular premises for inspection based on neutral criteria such as "the passage of time, the nature of the building ... or the condition of the entire area." Although not subject to easy definition, neutral criteria are distinguished from "specific knowledge of the condition of the particular dwelling." Camara found that probable cause to issue an inspection warrant exists if these neutral criteria "are satisfied with respect to a particular dwelling."

2. Limitations on the Scope of Administrative Searches. Although the administrative warrant issues on less than probable cause, it was fashioned to protect other "traditional safeguards which the Fourth Amendment guarantees to the individual" through the warrant requirement. 77 Thus, the scope of the search is limited to areas for which a showing of probability has been

force against the citizen." Frank v. Maryland, 359 U.S. 360, 382 (1959) (Douglas, J., dissenting) (citations omitted).

787 U.S. at 537.

72 Id. at 530. Cf. Wyman v. James, 400 U.S. 309, 323 (1971) (warrants not required for home visitations by welfare caseworkers, for a "caseworker is not a sleuth but rather, we trust, is a friend to one in need").

${ }^{73}$ See Marshall v. Barlow's, Inc., 436 U.S. 307, 323 (1978). The Court was concerned about possible abuse by inspectors. See note 79 infra.

${ }^{74} 387$ U.S. at 538. The Court in Marshall v. Barlow's, Inc., 436 U.S. 307, 321 (1978), referred to "neutral sources such as, for example, dispersion of employees in various types of industries across a given area, and the desired frequency of searches in any of the lesser divisions of the area."

$75^{\circ} 387$ U.S. at 538.

76 Id. For a discussion of neutral criteria in the context of OSHA administrative searches, see note 84 infra.

${ }^{77}$ Id. at 534. The Court considered such protection necessary to guard against abuse by inspectors. Id. at 532. See also See v. City of Seattle, 387 U.S. 541, 545 (1967). 
made; ${ }^{78}$ a neutral magistrate must narrowly draw the scope of the warrant authorizing that search; ${ }^{79}$ and the areas implicated and violations alleged must be described with particularity in the warrant. $^{80}$

The Secretary, then, is incorrect in arguing that warrants need only be "restricted to the subject matter regulated by the statute and other limitations imposed by Congress."81 The constitutionally permissible scope of a search is defined not by an agency's regula-

78 Camara noted that the warrant should be "suitably restricted," id. at 539, and included "the lawful limits of the inspector's power to search" as a matter for review by the magistrate, id. at 532. See LaFave, supra note 56, at 25-26. The Court in See v. City of Seattle, 387 U.S. 541 (1967), analogized such warrants to administrative subpoenas, which must be "sufficiently limited in scope, relevant in purpose, and specific in directive so that compliance will not be unreasonably burdensome." Id. at 544 (footnote omitted). See also Oklahoma Press Publishing Co. v. Walling, 327 U.S. 186, 209 (1946) ("relevancy and adequacy or excess in the breadth of the subpoena are matters variable in relation to the nature, purposes, and scope of the inquiry").

79 Camara v. Municipal Court, 387 U.S. 523, 532-33 (1967). Underlying the Court's administrative warrant decisions is the constant theme of guarding against abuses of discretion by inspectors. See Marshall v. Barlow's, Inc., 436 U.S. 307, 323 (1978) (criticizing the devolution of "almost unbridled discretion upon executive and administrative officers, particularly those in the field, as to when to search and whom to search"); See v. City of Seattle, 387 U.S. 541, 545 (1967); Camara v. Municipal Court, 387 U.S. 523, 532 (1967) (practical effect of warrantless inspections "is to leave the occupant subject to the discretion of the official in the field"). See generally Greenberg, The Balance of Interests Theory and the Fourth Amendment: A Selective Analysis of Supreme Court Action Since Camara and See, 61 Calir. L. Rev. 1011, 1023 (1973).

so See Marshall v. Barlow's, Inc., 436 U.S. 307, 323 (1978) (a warrant "advise[s] the owner of the scope and objects of the search, beyond which limits the inspector is not expected to proceed"); See v. City of Seattle, 387 U.S. 541, 545 (1967) (discussion of particularity requirement in the context of administrative subpoenas).

It has been argued that the Barlow's warrant requirement "does not purport to restrict [the inspection] power but simply to ensure that the employer is apprised of its scope." Marshall v. Barlow's, Inc., 436 U.S. at 334 (Stevens, J., dissenting); Marshall v. Berwick Forge \& Fabricating Co., 474 F. Supp. 104, 113 n.20 (M.D. Pa. 1979); Brief for the Secretary of Labor at 18-19, Marshall v. North Am. Car Co., 626 F.2d 320 (3d Cir. 1980). See also Blocksom \& Co. v. Marshall, 582 F.2d 1122, 1125 (7th Cir. 1978); In re Marsan Co., 7 Occ. Safety \& Health Cas. (BNA) 1557, 1559 (N.D. Ind. 1979). Cf. Marshall v. Seaward Int'l, Inc., 510 F. Supp. 314, 318 (W.D. Va. 1980) (only reasonable notice is required). This construction ignores the context of the Barlow's Court's language. That Court refuted the Secretary's argument that the Act and regulations "already protect as much privacy as a warrant would." 436 U.S. at 315 . The Act does limit the scope of OSHA inspections, see tert and notes at notes 20-51 supra, but it does not provide for informing the employer of the limits of a search; the compliance officer need only "indicate generally the scope of the inspection," 29 C.F.R. $\S 1903.7$ (a) (1981). The Court naturally focused on the inadequacy of this provision in pointing out the "incremental protections afforded the employer's privacy by a warrant." 436 U.S. at 322 . That the warrant requirement serves a notice function does not mean that it does not impose substantive limitations on scope as well.

ar Brief for the Secretary of Labor at 18-19, Marshall v. North Am. Car Co., 626 F.2d 320 (3d Cir. 1980). 
tory authority but by the locale-specific probability provided by its investigatory scheme. ${ }^{82}$ Areas not implicated by the scheme are outside this showing of probability and may not be searched.

The often wall-to-wall scope of section 8(a) programmed inspections ${ }^{83}$ is fully consistent with these principles. The breadth of such searches is justified by the administrative plan, which establishes the requisite likelihood that violations will be found. ${ }^{84} \mathrm{Be}-$ cause the hazards addressed in a programmed inspection plan often include the full spectrum of violations and dangers set forth in the Act, sufficient probability to search may exist throughout a facility. ${ }^{85}$

${ }^{82}$ The Secretary's argument would confine the magistrate's role to ensuring that the warrant does not exceed the inspector's statutory authority, an interpretation that would reduce his function to proofreading the statute as reprinted in the warrant. As Justice Stevens pointed out in arguing against the warrant requirement, such a reading renders both magistrate and warrant superfluous, Marshall v. Barlow's, Inc., 436 U.S. 307, 333 (1978) (Stevens, J., dissenting), and ignores the Court's declaration in Camara v. Municipal Court, 387 U.S. 523, 533 (1967), that "broad statutory safeguards are no substitute for individualized review." In See v. City of Seattle, 387 U.S. 541, 544 (1967), the Court found "strong support in [its administrative] subpoena cases for our conclusion that warrants are a necessary and tolerable limitation on the right to enter upon and inspect commercial premises," and it noted that the protections provided by an administrative subpoena are "constitutionally sufficient" if the inquiry is within the agency's authority, the demand is not too indefinite, and the information sought is reasonably relevant. See also United States v. Morton Salt Co., 338 U.S. 632, 652 (1950); Comment, supra note 63, at 78-85.

${ }^{83}$ See note 34 supra.

84 See text and notes at notes 74-76 supra. Although the case law remains confused and in a state of flux, it has been generally held that the applicant must provide data demonstrating the prevalence of hazards within an industry. See In re Northwest Airlines, Inc., 437 F. Supp. 533, 536 (E.D. Wis. 1977), aff'd, 587 F.2d 12 (7th Cir. 1978). See generally In re Gilbert \& Bennett Mfg. Co., 589 F.2d 1335, 1343 (7th Cir. 1979) (some substantiation, though minimal, required); Marshall v. Shellcast Corp., 5 Occ. Safety \& Health Cas. (BNA) 1689, 1690-91 (N.D. Ala. 1977), vacated on other grounds, 592 F.2d 1369 (5th Cir. 1979). A particular worksite within the industry must be selected on a rational, nondiscriminatory basis to ensure that it "was selected for inspection not as the result of the "unbridled discretion' of a field agent," but on the basis of neutral criteria. In re Gilbert \& Bennett Mfg. Co., 589 F.2d 1335, 1343 (7th Cir. 1979). The standard selection scheme is "worst-first." 9 Occ. Safety \& Health Rep. 533 (1979). See, e.g., Reynolds Metals Co. v. Secretary of Labor, 442 F. Supp. 195, 200-01 (W.D. Va. 1977). The ranking of the worksite on the worst-first list may not be disregarded without justification. Marshall v. Weyerhaeuser Co., 456 F. Supp. $474,483-84$ (D.N.J. 1978).

ss It also has been argued that "[b]ecause the exact location of violations cannot be known prior to entering the establishment, ... no meaningful limitation on scope [can] be devised" for programmed searches. In re Gilbert \& Bennett Mfg. Co., 589 F.2d 1335, 1343 (7th Cir. 1979); see also In re Marsan Co., 7 Occ. Safety \& Health Cas. (BNA) 1557, 1559 (N.D. Ind. 1979); LaFave, supra note 56, at 26. Whatever the validity of this view, it cannot justify broad complaint inspections, for the employee allegations give "the ability to determine the precise nature and location of the alleged violations." Marshall v. North Am. Car Co., 476 F. Supp. 698, 706 (M.D. Pa. 1979), aff'd, 626 F.2d 320 (3d Cir. 1980). 
This does not mean that all administrative searches may extend wall-to-wall, because Camara and See set up a "flexible standard of reasonableness." against the invasion which the search entails" ${ }^{87}$ must be done afresh when the elements in the balance are altered. For example, in Michigan $v$. Tyler, ${ }^{88}$ a case imposing the warrant requirement on administrative investigations into the origins of fires, ${ }^{89}$ the Court noted that such investigations "are not programmatic but are responsive to individual events"; it therefore held that "a more particularized inquiry [by the magistrate] may be necessary" into "the purpose, frequency, scope, and manner of conducting the inspections." 90 The Court noted that the warrant requirement enables "the magistrate [to] perform the important function of preventing harassment by keeping [the] invasion to a minimum."”1

\section{Limits on the Scope of Complaint Inspections}

Against this background, the Secretary's contention that receipt of an employee complaint justifies a wall-to-wall inspection-in effect, that the complaint provides the same showing of probable cause as the neutral plan-must fail. The argument is like comparing apples and oranges. Complaint inspections are

${ }^{88}$ See v. City of Seattle, 387 U.S. 541, 545 (1967).

${ }^{87}$ Camara v. Municipal Court, 387 U.S. 523, 537 (1967).

88436 U.S. 499 (1978).

89 The Court distinguished administrative searches to investigate the causes of fires from routine fire code inspections, traditional warrantless emergency entries to extinguish fires, and criminal arson investigations. The Court's extensive identification of fire inspections with health and safety inspections, $i d$. at 504-05, 508, 511, undermines the claim made, for example, in Burkart Randall Div. of Textron, Inc. v. Marshall, 625 F.2d 1313, 1318 n.5 (7th Cir. 1980) (Sprecher, J.), that Tyler's "language must be considered limited to the context of fire inspections." One need look no further than See v. City of Seattle, 387 U.S. 541, 545-46 (1967), itself a fire inspection case, for authority to the contrary.

90 436 U.S. at 507 (emphasis added); see Marshall v. Horn Seed Co., 647 F.2d 96, 100 (10th Cir. 1981); Marshall v. Central Mine Equip. Co., 608 F.2d 719, 720 \& n.1 (8th Cir. 1979). The Secretary simply misreads Tyler in arguing that "the phrase 'particularized inquiry' did not refer to the scope of the inspection but rather to the issue of whether an inspection should be authorized by the magistrate." Brief for the Secretary of Labor at 20 n.15, Marshall v. North Am. Car Co., 626 F.2d 320 (3d Cir. 1980).

21436 U.S. at 508. The Secretary has sought to distinguish OSHA complaint searches from fire inspections on the ground that complaint inspections "contain elements of both routine . . . and investigatory searches"; investigation of the "individual event" (the complaint) is not the OSHA inspector's "only legitimate purpose for entry." Reply Brief for the Secretary of Labor at 2 \& n.1, Marshall v. North Am. Car Co., 626 F.2d 320 (3d Cir. 1980) (quoting Rothstein, supra note 17, at 91). This argument is circular: complaint inspections contain both elements only because the Secretary asserts the right to carry them out in that manner. 
based on a different genre of probability, confined to particular areas, and raise serious problems of intrusiveness and abuse not implicated by programmed inspections. Because of these distinctions, a greater quantum of probability is required before an area can be inspected in a complaint search.

1. Probable Cause. A complaint inspection rests on a showing of probability altogether different from that made for a programmed inspection. The magistrate is presented not with an objective administrative plan addressing a variety of possible hazards, but only with allegations of a particular violation or danger. ${ }^{92}$ Whereas a plan implicates an entire facility, the complaint designates a specific location. ${ }^{93}$ By providing "specific evidence"94 of the existence of a violation, the complaint establishes a high level of strictly localized probability clearly sufficient to justify investigation of the alleged hazard. ${ }^{95}$ Similarly, if the alleged viola-

92 Vague, general descriptions do not justify a broad search; to the contrary, they fail to establish probable cause at all. See In re ASARCO, Inc., 508 F. Supp. 350, 354 (N.D. Tex. 1981) (complaint alleged "poor housekeeping"; "The issuance of a wall-to-wall warrant on such general allegations would render meaningless the warrant requirement . . . ."). Moreover, if the Secretary does find reasonable grounds to inspect hazards other than those alleged on the face of the complaint, he must specify the additional targets for inspection. Conclusory statements that "it is also reasonable to believe that other violations besides those described may exist" are insufficient. Marshall v. Trinity Indus., Inc., 7 Occ. Safety \& Health Cas. (BNA) 1851, 1854 (W.D. Okla. 1979).

The courts divide over whether the magistrate should be presented with the original complaint. Compare Marshall v. Horn Seed Co., 647 F.2d 96, 103 (10th Cir. 1981) (complaint should be attached to warrant application) with In re Gilbert \& Bennett Mfg. Co., 559 F.2d 1335, 1338 (7th Cir. 1979); Marshall v. North Am. Car Co., 476 F. Supp. 698, 704 (M.D. Pa. 1979), aff'd, 626 F.2d 320 (3d Cir. 1980); and In re Marsan Co., 7 Occ. Safety \& Health Cas. (BNA) 1557, 1560 (N.D. Ind. 1979) (presentation of complaint unnecessary).

"3 Repetition of the "boilerplate" language of the Act also is insufficient to satisfy the requirement that location be identified. See Marshall v. Wollaston Alloys, Inc., 479 F. Supp. 1102, 1104 (D. Mass. 1979); Marshall v. Pool Offshore Co., 467 F. Supp. 978, 981-82 (W.D. La. 1979).

For a discussion of the degree of particularity required in identifying the location of the alleged hazards, see BP Oil, Inc. v. Marshall, 509 F. Supp. 802 (E.D. Pa. 1981) (although holding that the identity of the violation must be described with particularity, the court reserved the question of the relationship between the violation and the area implicated). See also J.R. Simplot Co. v. Marshall, 640 F.2d 1134 (9th Cir. 1981) (reasonable and good faith effort to identify the location of the hazard required), petition for cert. filed, 50 U.S.L.W. 3404 (U.S. Sept. 21, 1981) (No. 81-863). The proper standard would require particular description of the violation's location as a corollary to the description of the hazard and of the area for which probable cause has been shown.

2 Marshall v. Barlow's, Inc., 436 U.S. 307, 320 (1978); see also Marshall v. Horn Seed Co., 647 F.2d 96, 103 (10th Cir. 1981) ("The warrant application must . . . inform the magistrate of the substance of the complaint so that he can determine whether the alleged conditions, if true, constitute a violation.") (citation omitted).

${ }^{95}$ The level of probability approaches criminal probable cause, but should not be held 
tion has manifestations elsewhere, the complaint also may provide an adequate level of probability for the search of those areas. ${ }^{98} \mathrm{Fi}-$ nally, the complaint may supply Camara-level probability that a search of similar areas in the facility would reveal similar violations. ${ }^{\text {g7 }}$

As to all other areas of the establishment, however, the complaint fails to supply even Camara-level probability. The complaint cannot justify a search for violations it does not allege in areas it does not mention..$^{83}$ Neither the quantity, nor the location,

to that high standard. See text and notes at notes $129-131$ infra. The only requirement of criminal probable cause not ordinarily satisfied is demonstration of the complainant's reliability. See note 60 supra. Several courts have held that an OSHA warrant application need not "demonstrate a reason to believe that the complainant is a credible person." In re Gilbert \& Bennett Mfg. Co., 589 F.2d 1335, 1339 (7th Cir. 1979). See also Burkhart Randall Div. of Textron, Inc. v. Marshall, 625 F.2d 1313, 1320 (7th Cir. 1980); Weyerhaeuser Co. v. Marshall, 592 F.2d 373, 377 (7th Cir. 1979); In re Cargill, Inc., 9 Occ. Safety \& Health Cas. (BNA) 1652, 1653 (N.D. Tex. 1981); BP Oil, Inc. v. Marshall, 509 F. Supp. 802, 806 (E.D. $\mathrm{Pa}$. 1981). Other courts have held that although the degree of reliability necessary for criminal probable cause is not required, some demonstration must be made that the complainant is a "reasonably reliable and credible source." In re Central Mine Equip. Co., 7 Occ. Safety \& Health Cas. (BNA) 1185, 1188 \& n.4 (E.D. Mo.), vacated on other grounds sub nom. Marshall v. Central Mine Equip. Co., 608 F.2d 719 (8th Cir. 1979). Cf. In re Northwest Airlines, Inc., 437 F. Supp. 533, 536 (E.D. Wis. 1977) (magistrate must be provided with factual data giving rise to belief that violation exists), aff'd, 587 F.2d 12 (7th Cir. 1978); Tran-Tec. Corp., 9 Occ. Safety \& Health Cas. (BNA) 1203, 1204 (OSHRC 1980) (denying warrant based on unsworn employee complaint). See also Marshall v. Horn Seed Co., 647 F.2d 96, 102-03 (10th Cir. 1981); Marshall v. W\&W Steel Co., 604 F.2d 1322, 1326 (10th Cir. 1979); West. Point-Pepperell, Inc., v. Marshall, 496 F. Supp. 1178, 1183 (N.D. Ga. 1980).

96 See Marshall v. North Am. Car Co., 626 F.2d 320, 324 (3d Cir. 1980); Marshall v. North Am. Car Co., 476 F. Supp. 698, 705 (M.D. Pa. 1979) (discussing Marshall v. Silberline Mfg. Co., No. 77-24 (M.D. Pa. Oct. 20, 1977)), aff'd, 626 F.2d 320 (3d Cir. 1980); Comment, supra note 63, at 95-96. Cf. Marshall v. Seaward Int'l Inc., 510 F. Supp. 314, 318 (W.D. Va. 1980) (exposure to toxic materials). Such a level of probable cause satisfies a "reasonable belief" standard. See text and notes at notes 128-135 infra.

"7 See Burkart Randall Div. of Textron, Inc. v. Marshall, 625 F.2d 1313, 1328 (7th Cir. 1980) (Wood, J., dissenting). This does not mean that a complaint inspection may extend into these areas. See text and notes at notes 101-110, 136 infra.

9s It has been argued that the complaint gives "probable cause to believe that a particular workplace is not entirely safe." Burkart Randall Div. of Textron, Inc. v. Marshall, 625 F.2d 1313, 1325 (7th Cir. 1980) (Sprecher, J.). Probability that one hazard exists, however, does not in itself meet the fourth amendment's particularity and probable cause requirements as to other violations in other areas. This "tip of the iceberg" assumption "is indeed approval of general warrants in every conceivable case." Id. at 1327 (Wood, J., dissenting). Although the extent of the alleged violations might suggest the existence of other violations by implying a disregard for safety by the employer, there is an equally plausible contrary inference: if the complainant knew of other hazards he would have complained of them as well. See also Donovan v. Huffines Steel Co., 645 F.2d 288, 291 (5th Cir. 1981) (Rubin, J., concurring). It has been argued, however, that the complaining "employee is normally familiar [only] with limited areas," Burkart Randall Div. of Textron, Inc. v. Marshall, 625 F.2d 1313, 1324 (7th Cir. 1980) (Sprecher, J.) (quoting In re Wisconsin Steel, No. 79-C-4284, 
nor the type of violations alleged ${ }^{98}$ legitimately support an inference that violations not complained of will be found in undetailed locations. ${ }^{100}$

2. Intrusiveness. Like the investigatory fire searches considered in Tyler, OSHA complaint inspections must be subjected to "more particularized inquiry" by the magistrate. 101 The intrusiveness and potential for abuse of complaint inspections require a new balance to be struck between "the need for the intrusion on the one hand, and the threat of disruption to the occupant on the

mem. op. at 2-3 (N.D. Ill. Dec. 28, 1979)). But employees in other areas may be expected to complain and to be equally aware of their right to do so.

To justify a broader search, OSHA therefore at least must show "that where violations of [this] type . . . are found to exist it is probable that other . . . violations exist in other parte of" such facilities. Marshall v. North Am. Car Co., 476 F. Supp. 698, 707 (M.D. Pa. 1979), aff'd, 626 F.2d 320 (3d Cir. 1980). See note 24 supra. Simply to contend that "OSHA inspectors executing a limited warrant will probably observe conditions that would lead them to suspect other violations," Marshall v. Central Mine Equip. Co., 608 F.2d 719, 720 (8th Cir. 1979), or that "agency experience indicates that complaint inspections result in the discovery of at least as many hazards not related to the complaint as are related to the complained-of working conditions," OSHA INSTRUCTION CPL $2.12 \mathrm{~A} \& \mathrm{~K}$, reprinted in 1979 Occ. Safety \& Health REr. File (BNA) 21:8177, :8180, does not provide the magistrate with the necessary particularity. Moreover, such assertions may indicate more about the triviality of OSHA citations and the often groundless nature of complaints than about probability. See note 109 infra.

\% The quantity of alleged violations, e.g., Marshall v. Berwick Forge \& Fabricating Co., 4.74 F. Supp. 104, 112-13 (M.D. Pa. 1979) (170 alleged violations justified wall-to-wall search); Empire Steel Mfg. Co. v. Marshall, 437 F. Supp. 873 (D. Mont. 1977) (80 alleged violations; limited warrant issued); the location of those violations in the facility, e.g., Burkart Randall Div. of Textron, Inc. v. Marshall, 625 F.2d 1313, 1326 (7th Cir. 1980) (Fairchild, C.J., concurring) (violations were "sufficiently diffuse" to justify wall-to-wall search); In re ASARCO, Inc., 508 F. Supp. 350, 352 (N.D. Tex. 1981) (Secretary argued that alleged violations were "so pervasive and covered so much of the work place as to provide probable cause to believe that violations existed throughout the refinery"); Marshall v. North Am. Car Co., 476 F. Supp. 698, 706-07 (M.D. Pa. 1979) (complaints may be "so pervasive" as to justify wall-to-wall search), aff'd, 626 F.2d 320 (3d Cir. 1980); and the total area of the facility implicated by the alleged violations, e.g., Marshall v. Berwick Forge \& Fabricating Co., 474 F. Supp. 104, 112-13 (M.D. Pa. 1979) (wall-to-wall search justified where 300,000 square feet, $15 \%$ of the workplace, were implicated), in themselves give inadequate cause to believe that hazards exist in unmentioned locations. See note 98 supra. To argue that because the search is broad it should be broader is inconsistent with the requirement that government intrusions on privacy be as narrow as possible. See text and notes at notes $55-59,78-80$ supra.

${ }^{100}$ It has been argued that to require a showing of probable cause for each part of the employer's facility "would render meaningless the Supreme Court pronouncement in Barlow's that the Secretary's 'entitlement to inspect will not depend on his demonstrating probable cause to believe that conditions in violation of OSHA exist on the premises' . . ." In re Gilbert \& Bennett Mfg. Co., 589 F.2d 1335, 1344 (7th Cir. 1979) (quoting Marshall v. Barlow's, Inc., 436 U.S. 307, 320 (1978)). Reference to the context of this quotation, however, shows that it referred to "[p]robable cause in the criminal law sense." 436 U.S. at 320.

${ }^{101}$ Michigan v. Tyler, 436 U.S. 499, 507 (1978). See text and notes at notes 86-91 supra. 
other."102

As in Tyler, OSHA complaint inspections are not programmatic, but responsive to individual events. ${ }^{103}$ Employees and union representatives may make complaints to harass employers. ${ }^{104}$ The participation of these parties in the actual inspection ${ }^{105}$ may be exploited to pressure the inspector to exceed the proper bounds of his search. Moreover, the procedure remains open to harassing administration by OSHA officials themselves. ${ }^{106}$ Because the inspection is a response to allegations of specific wrongdoing, the inspec-

102 Michigan v. Tyler, 436 U.S. 499, 507 (1978).

${ }^{105}$ Such searches are even more intrusive than investigatory fire searches because they are triggered by human demands for the search. See Comment, Fourth Amendment Implications of Warrantless Occupational Safety and Health Act Inspections, 82 Dick. L. REv. 773, 796 (1978).

${ }^{104}$ For examples of employee harassment, see BP Oil, Inc. v. Marshall, 509 F. Supp. 802 (E.D. Pa. 1981). In that case, the union filed two imminent danger complaints during a strike, then later "sent a telegram to OSHA advising it that the strike had ended and that [the union] wanted to withdraw [its] complaints against BP." Id. at 805. OSHA nevertheless insisted on continuing its investigation and met with the union to draft a "revised list of hazards." Id. In another case, the employer was inspected 23 times while comparable establishments were inspected no more than 3 times. The majority of these inspections were prompted by employee complaints, and on those occasions when the complaints were groundless, the inspectors were "forced by union members to investigate other situations" until eventually some violation was discovered. In a letter to the Assistant Secretary, the employer pleaded that the union "had found OSHA to be a convenient tool in a program of harassment in an effort to obtain concessions which have no relation to safety and health." Nevertheless, the union called for inspectors a twenty-fourth time, and they arrived demanding entry to make a wall-to-wall search. Dravo Corp. v. Marshall, 5 Occ. Safety \& Health Cas. (BNA) 2057, 2059 (W.D. Pa. 1977), aff'd, 578 F.2d 1373 (3d Cir. 1978); see Dravo Corp. v. OSHRC, 613 F.2d 1227 (3d Cir. 1980).

${ }^{105}$ An authorized employee representative may accompany the inspector, 29 U.S.C. $\S$ 657(e) (1976), and may make further complaints during the inspection, id. $\S 657(f)(2)$.

${ }^{106}$ See Marshall v. Horn Seed Co., 647 F.2d 96, 101 (10th Cir. 1981) (absent an administrative plan, "the danger of arbitrary invasions of governmental officials exists. There are no administrative or legislative guidelines assuring us that the target was not chosen for purposes of harassment."). OSHA has promoted excessive zeal by setting quotas for, and evaluating its compliance officers according to, "the number of inspections conducted or violations cited." Whiting, supra note 30, at 262. See also Marshall v. North Am. Car Co., 476 F. Supp. 698, 700-02 (M.D. Pa. 1979) (facts suggested that inspectors' actions were in retaliation for warrant request, see note 14 supra), aff'd, 626 F.2d 320 (3rd Cir. 1980); Electrocast Steel Foundry, Inc., 6 Occ. Safety \& Health Cas. (BNA) 1562, 1563 (OSHRC 1978) (employer alleged that his insistence that OSHA obtain a warrant prompted the agency to convert the inspection into a wide-ranging search resulting in " $\mathrm{a}$ host of non-serious, nitpicking citations").

Political pressure also may provoke improper inspections. When questioned about excessive inspections, one area director explained that "if he did not promptly service certain of these complaints, he might, and often did, get pressure from people in political life, including Congressmen, to make greater effort." Dravo Corp. v. Marshall, 5 Occ. Safety \& Health Cas. (BNA) 2057, 2059 (W.D. Pa. 1977), aff'd, 578 F.2d 1373 (3d Cir. 1978). 
tors enter with suspicions aroused against the particular employer, leading to a "hostile" search that is "personal in nature."10z The broad discretion allowed in programmed inspections is likely to be abused where inspectors entering in pursuit of evidence of alleged hazards are permitted to extend the scope of their searches. ${ }^{108}$ In short, despite statutory safeguards, ${ }^{109}$ the focused, hostile nature of

107 Camara .v. Municipal Court, 387 U.S. 523, 530, 537 (1967).

${ }^{108}$ The need for a check is apparent: on the basis of limited complaints, OSHA has asserted the right not only to inspect literally "wall-to-wall," but also to inspect every building and yard in a seventy-acre establishment, Marshall v. North Am. Car. Co., 626 F.2d 320 (3d Cir. 1980); to inspect entire facilities in two separate and distant locations operated by the same employer, Whittaker Corp. v. OSHA, 6 Occ. Safety \& Health Cas. (BNA) 1495 (M.D. Pa. 1978), appeal dismissed, 594 F.2d 855 (3d Cir. 1979); and to inspect other employers at the same worksite, Marshall v. Pool Offshore Co., 467 F. Supp. 978 (W.D. La. 1979).

It has been argued that the warrant procedure adequately protects the employer even where the warrant's scope is not narrowly drawn. Burkart Randall Div. of Textron, Inc. v. Marshall, 625 F.2d 1313, 1324-25 (7th Cir. 1980) (Sprecher, J.); In re Chicago Magnet Wire Corp., 5 Occ. Safety \& Health Cas. (BNA) 2024, 2025 (N.D. Ill. 1977) ("The probable cause requirement protects against mere 'fishing expeditions,' and once that requirement is met, the compliance official may be permitted to make an inspection of the entire worksite."); In re Gilbert \& Bennett Mfg. Co., 5 Occ. Safety \& Health Cas. (BNA) 1375, 1375-76 (N.D. Ill. 1977), aff'd on other grounds, 589 F.2d 1335 (7th Cir. 1979); Comment, Administrative Searches and the Fourth Amendment's Warrant Requirement, 32 ARK. L. REv. 755, 769 (1979). The probable cause requirement guards against fishing expeditions, however, only if the search is restricted to those areas for which probable cause is shown. If the magistrate need only determine whether there is probable cause to enter a facility and does not limit the scope of the search within that facility, the officer's discretion remains unchecked. The inspectors have no more right to wander if they enter on probable cause limited to one area than if they enter with consent limited to one area. See, e.g., Stephenson Enterprises, Inc. v. Marshall, 578 F.2d 1021, 1024 \& n.2 (5th Cir. 1978); Lake Butler Apparel Co. v. Secretary of Labor, 519 F.2d 84; 88 (5th Cir. 1975); Advance Foundry Corp., 10 Occ. Safety \& Health Cas. (BNA) 1104, 1104 (OSHRC 1981); Merchants Oil, Inc., 8 Occ. Safety \& Health Cas. (BNA) 1162, 1163 (OSHRC 1979); Keco Indus., Inc., 7 Occ. Safety \& Health Cas. (BNA) 2048, 2054 (OSHRC 1979) (digest of administrative law judge opinion) (all involving the limits on consent inspections).

${ }^{109}$ Although proclaiming that it "of course does not intend to be used as a harassment device," 45 FED. REG. 65,916, 65,922 (1980), OSHA in practice has disregarded each of the statutory safeguards discussed in note 29 supra. The agency has instructed that administrators "shall conduct a thorough evaluation of all complaints, regardless of the complaint's formality." Field Manual, ch. VI, § E.1.a, reprinted in 1981 Occ. Safety \& Health Ref. FILE (BNA) 77:2701. Thus it has inspected on the basis of complaints from competitors and former employees, see note 39 supra, groups that have no direct contact with the hazards they allege and that are likely to be motivated more by ill will than by concern for the safety of others. OSHA has even acted on anonymous telephone complaints. E.g., In re Quality Prods., 6 Occ. Safety \& Health Cas. (BNA) 1663 (D.R.I. 1978). OSHA also will respond to complaints setting forth merely "a violation of the Act," 29 C.F.R. § 1903.11(a) (1981), including violations of standards not threatening physical harm and violations of the General Duty Clause, 29 U.S.C. $\S 654(a)(1)$ (1976). The opportunities for harassment are multiplied by the over 5,000 "consensus" safety standards, "many of them trivial and unrelated to actual workplace hazards," pursuant to which compliance officers, "lacking the latitude to 
the complaint inspection and the potential for private vendettas combine to produce grave risks of abuse. ${ }^{110}$ The Camara balancing test therefore requires a higher level of probability to justify the intrusion.

3. Opposing Arguments. The Secretary has argued, however, that "expediency dictates" a search broader than the allegations in the complaint because a wall-to-wall search is the most efficient use of limited compliance resources. ${ }^{111}$ Extending a complaint inspection wall-to-wall is a perverse method of conserving scarce resources, however. ${ }^{112}$ Expansive complaint inspections could only be

apply common sense to enforcement, wrote up everything from coat-hooks to split toilet seats." Bingham, OSHA: Only Beginning, 29 LAB. L.J. 131, 131 (1978).

By proclaiming the motive of the complainant irrelevant, OSHA effectively has discarded the requirement that the employee "believe" that the alleged hazards exist. 45 FED. REG. 65,916, 65,922 (1980); see OSHA INSTRUction CPL 2.12A, \& H, reprinted in 1979 Occ. SAFETY \& HeALTH REr. FILE (BNA) 21:8177, :8178-79. The OSHRC has ignored evidence that the complaint was not from a reasonably reliable and credible source. See Hydraform Prods. Corp., 7 Occ. Safety \& Health Cas. (BNA) 1995, 1996 (OSHRC 1979) ("even if the complainant's motive was harassment, it would not invalidate the inspection"); Aluminum Coil Anodizing Corp., 5 Occ. Safety \& Health Cas. (BNA) 1381 (OSHRC 1977); Aluminum Coil Anodizing Corp., 1 Occ. Safety \& Health Cas. (BNA) 1508 (OSHRC 1974); note 95 supra.

The result of OSHA's dilution of these protections against harassment is that $90 \%$ of all complaints result in inspection. 8 Occ. Safety \& Health Rep. (BNA) 1674 (1979); Rothstein, supra note 17, at 85. A recent Government Accounting Office ("GAO") study found that $70 \%$ of the hazards found in complaint inspections are not serious and that most complaints "do not appear to address serious hazards or, in some cases, any hazards." 8 Occ. Safety \& Health Rep. (BNA) 1674 (1979); see 45 FED. REG. 65,916, 65,916-17 (1980) (noting argument of some commentators "that a preponderance of complaints about hazardous conditions are groundless"); OSHA INSTRUCTION CPL 2.12A \& F.1, reprinted in 1979 Occ. SAFETY \& HeAlTh REP. FILE (BNA) 21:8177, :8178 (noting GAO's finding of "numerous complaints which resulted in comparatively few serious violations related to the complained of hazards").

${ }^{110}$ The danger of harassment is heightened by the Secretary's directive that " $[e] x$ parte inspection warrants shall be the preferred form of compulsory process." 29 C.F.R. $\S$ 1903.4(d) (1981). See Donovan v. Huffines Steel Co., 645 F.2d 288, 288-91 (5th Cir. 1981) (Rubin, J., concurring). Without an opportunity to be present at the warrant hearing, the employer is highly vulnerable given the limited ability of a magistrate to detect ill motive independently. See, e.g., West Point-Pepperell, Inc. v. Marshall, 8 Occ. Safety \& Health Cas. (BNA) 1954, 1960 (N.D. Ga. 1980); In re CF\&I Steel Corp., 489 F. Supp. 1302, 1312 (D. Colo. 1980) ("If proof positive were needed that sweeping OSHA search warrants should not be routinely issued ex parte, this case provides that proof."); LaFave, supra note 56, at 25. But see Comment, supra note 103, at 791 n.46.

111 Brief for the Secretary of Labor at 17 n.12, Marshall v. North Am. Car. Co., 626 F.2d 32 (3d Cir. 1980); see also Marshall v. Central Mine Equip. Co., 608 F.2d 719, 720 (8th Cir. 1979); Comment, supra note 108, at 768-69.

112 The Secretary has acknowledged that complaint inspections absorb too much of OSHA's limited manpower. See Whiting, supra note 30, at 265. Because most complaints come from low-hazard businesses, 8 Occ. Safety \& Health Rep. (BNA) 1674 (1979), a policy 


\section{so justified if they either obviated the need for a programmed search or rendered future complaint inspections unnecessary. ${ }^{113}$ The first efficiency is possible only if the establishment is due for a}

of investigating all complaints "adversely affect[s] OSHA's ability to concentrate its resources in high hazard areas to conduct programmed inspections." OSHA INSTRUCTION CPL 2.12A § F.1, reprinted in 1979 Occ. SAFETY \& HeAlth REF. Fne (BNA) 21:8177, :8178. The Secretary now seeks wall-to-wall complaint inspections primarily in high-hazard industries, id. $\S \mathrm{K}$, reprinted in 1979 Occ. SAFETY \& HeALTH REr. FiLE (BNA) at 21:8180, so as to free "enforcement resources so that they can be employed where they are most needed." Whiting, supra note 30 , at 265 . See also Rothstein, supra note 17, at 96 (wall-to-wall inspections "may not make the most efficient use of resources and may be a needless burden on employers").

11s It could be argued that a search of limited scope is by its very nature inefficient because it will neglect nearby violations. See Marshall v. Seaward Int'l, Inc., 510 F. Supp. 314, 318 (W.D. Va. 1980). OSHA inspectors need not execute a limited warrant as if blinkered, however. Under the plain view doctrine, evidence "falling in the plain view of an officer who has a right to be in the position to have that view [is] subject to seizure." Harris v. United States, 390 U.S. 234, 236 (1968). See also Coolidge v. New Hampshire, 403 U.S. 443, 464-72 (1971); Harris v. United States, 331 U.S. 145, 155 (1947), overruled in part, Chimel v. California, 395 U.S. 752, 758 (1969). This criminal law principle applies to administrative searches as well. Donovan v. Burlington Northern, Inc., 10 Occ. Safety \& Health Cas. (BNA) 1175, 1178 n.3 (D. Mont. 1981). See Michigan v. Tyler, 436 U.S. 499, 509 (1978); Lake Butler Apparel Co. v. Secretary of Labor, 519 F.2d 84, 88 (5th Cir. 1975) (violations discovered during consent search "were in plain, obvious view"); In re Central Mine Equip. Co., 7 Occ. Safety \& Health Cas. (BNA) 1185, 1190 (E.D. Mo.), vacated on other grounds sub nom. Marshall v. Central Mine Equip. Co., 608 F.2d 719 (8th Cir. 1979). The violations need not be identical to those alleged in the warrant. In re ASARCO, Inc., 508 F. Supp. 350, 351, 353 (N.D. Tex. 1981).

The plain view doctrine, however, "may not be used to extend a general exploratory search from one object to another until something incriminating at last emerges." Coolidge v. New Hampshire, 403 U.S. 443, 466 (1971). The inspector may not leave the area in which he has a right to be or cite violations he cannot see in full, Keco Indus., Inc., 7 Occ. Safety \& Health Cas. (BNA) 2048, 2054 (OSHRC 1979) (consent inspection), or otherwise do more than observe violations apparent from his position of right, Merchants Oil, Inc., 8 Occ. Safety \& Health Cas. (BNA) 1162, 1163 (OSHRC 1979) (testing of hoses in plain view not permitted by the plain view exception). But see Protection Sprinkler Co., 2 Occ. Safety \& Health Cas. (BNA) 3205, 3206 (OSHRC 1974).

One commentator has suggested that if "during the course of the inspection the compliance officer determines that a broader inspection is necessary to protect the safety and health of affected employees," the officer should be able to extend his warranted inspection into a wall-to-wall search. Rothstein, supra note 17 , at 96 . Such a rule would be susceptible to abuse by inspectors and hostile employees. See text and notes at notes 104-108 supra. Given the concern of both Congress and the Court about such abuse, see text and notes at notes 26-29, 77-80 supra, inspectors should be allowed to exceed the scope of the warrant only in "emergency situations." See Camara v. Municipal Court, 387 U.S. 523, 539 (1967). Any suspicions left unconfirmed by observation from the position of right can be used to establish probable cause for a subsequent warranted inspection. See, e.g., In re Marsan Co., 7 Occ. Safety \& Health Cas. (BNA) 1557 (N.D. Ind. 1979); Blocksom \& Co. v. Marshall, 6 Occ. Safety \& Health Cas. (BNA) 1001, 1006, 1014 (N.D. Ind. 1977), aff'd on other grounds, 582 F.2d 1122 (7th Cir. 1978). Cf. Michigan v. Tyler, 436 U.S. 499, 511 (1978) (follow-up entries require warrant). 
programmed inspection; ${ }^{114}$ even then, the two searches should be conducted separately because the hostile suspicions of the complaint inspector may infect the exercise of his discretion in conducting the broader search. ${ }^{116}$ The second efficiency obtains only if the Secretary could "dismiss subsequent complaints as unfounded in the light of the previous inspection";116 experience has shown he cannot."17 Even if wall-to-wall searches are somewhat more "efficient," the marginal gains in efficiency do not outweigh the added burden to the employer caused by extending hostile complaint inspections into areas for which probable cause has not been shown. ${ }^{118}$

The Secretary also has asserted that because employers might prepare "sanitized areas" for inspection, it is necessary to scour the entire establishment. ${ }^{119}$ This argument makes eminent sense in the

114 The use of a complaint to justify an out-of-sequence plan inspection would destroy the routine and neutral nature of the selection process. See Marshall v. Horn Seed Co., 647 F.2d 96, 101 n.4 (10th Cir. 1981); Marshall v. Weyerhaeuser Co., 456 F. Supp. 474, 483 (D.N.J. 1978) ("the whole purpose of administrative probable cause . . . is to ensure neutral application of OSHA inspection procedures to a particular establishment. A selection of a plant or business must be based on neutral criteria from the outset to make sure that there is no harassment or subterfuge in the process.") (emphasis in original); note 84 supra. But see In re Urick Property, 472 F. Supp. 1193, 1195 (W.D. Pa. 1979) (suggesting that employee complaints may form part of a general administrative plan); Marshall v. Shellcast Corp., 5 Occ. Safety \& Health Cas. (BNA) 1689, 1694 (N.D. Ala. 1977); Note, Warrantless Nonconsensual Searches under the Occupational Safety \& Health Act of 1970, 46 Geo. WASH. L. REV. 93, 111 (1977).

${ }^{118}$ See text and notes at notes 106-108 supra.

116 Brief for the Secretary of Labor at 20 n.13, Marshall v. North Am. Car Co., 626 F.2d 320 (3d Cir. 1980); see OSHA INSTRUCTION CPL 2.12A § H.2.c, reprinted in 1979 Occ. SafeTy \& Health Ref. Fine (BNA) 21:8177, :8179.

${ }_{117}$ See Dravo Corp. v. Marshall, 5 Occ. Safety \& Health Cas. (BNA) 2057, 2059 (W.D. $\mathrm{Pa}$. 1977) (area director ordered 24 inspections of the facility despite his knowledge "that the plant in question is comparatively safe"), aff'd, 587 F.2d 1373 (3d Cir. 1978); In re Chicago Magnet Wire Corp., 5 Occ. Safety \& Health Cas. (BNA) 2024, 2024-25 (N.D. Ill. 1977) (two recent inspections did not prevent a third); FIELd Manual ch. IV, § B.3.c.(5), reprinted in 1981 Occ. SareTY \& Health Rep. File (BNA) 77:2304 ("a very recent inspection" will not foreclose response to a complaint).

The Secretary also has argued that a general inspection in response to a complaint spares the employer the disruption of a series of separate, limited inspections. Burkart Randall Div. of Textron, Inc. v. Marshall, 625 F.2d 1313, 1324 (7th Cir. 1980) (Sprecher, J.). The argument presupposes that by making a general inspection, the Secretary will be able to dismiss subsequent complaints. Even if that were so, the employer need only consent to a wall-to-wall search if he concurs with the Secretary's assessment of his convenience.

118 See text and note at note 67 supra.

110 Brief for the Secretary of Labor at 19, Marshall v. North Am. Car Co., 626 F.2d 320 (3d Cir. 1980). See also Burkart Randall Div. of Textron, Inc. v. Marshall, 625 F.2d 1313, 1324, 1325 (7th Cir. 1980) (Sprecher, J.); In re Marsan Co., 7 Occ. Safety \& Health Cas. (BNA) 1557, 1559 (N.D. Ind. 1979); In re Chicago Magnet Wire Co., 5 Occ. Safety \& Health 
context of programmed inspections ${ }^{120}$ and none whatsoever when the issue is the scope of complaint inspections. The complaint informs the Secretary of the location of the alleged violations; within the limits of probable cause he, not the employer, chooses the areas to be inspected. ${ }^{121}$

The assertion that the fourth amendment should be applied in light of the Act's remedial purposes ${ }^{122}$ is similarly flawed. Remedial motives "cannot supply probable cause, even under the most flexible standard, where it does not otherwise exist."123

Finally, it has been argued that it is "anomalous" to restrict the scope of an OSHA inspection when evidence of specific violations exists, while allowing wall-to-wall searches when the agency has no evidence of violations. ${ }^{124}$ In that the narrower scope results from the more localized showing of probability, there is no paradox. ${ }^{125}$ With regard to the more stringent requirement of probability imposed when OSHA acts on "specific evidence of an existing violation," 126 an anomaly undeniably exists. To challenge it, though, is to challenge the basic premise underlying the administrative warrant: that the probability demanded by the warrant

Cas. (BNA) 2024, 2025 (N.D. Ill. 1977).

${ }^{120}$ See In re Gilbert \& Bennett Mfg. Co., 598 F.2d 1335, 1343 (7th Cir. 1979).

${ }^{121}$ Ex parte warrants, see note 110 supra, give the employer no advance notice or opportunity to conceal what the employee has observed.

${ }^{122}$ See Burkart Randall Div. of Textron, Inc. v. Marshall, 625 F.2d 1313, 1324-25 (7th Cir. 1980) (Sprecher, J.); In re Gilbert \& Bennett Mfg. Co., 5 Occ. Safety \& Health Cas. (BNA) 1375, 1375 (N.D. Ill. 1977), aff'd on other grounds, 589 F.2d 1335 (7th Cir. 1979).

${ }^{123}$ Burkart Randall Div. of Textron, Inc. v. Marshall, 625 F.2d 1313, 1328 (7th Cir. 1980) (Wood, J., dissenting). Consider also the cautionary words of Justice Brandeis:

Experience should teach us to be most on our guard to protect liberty when the Government's purposes are beneficent. Men born to freedom are naturally alert to repel invasion of their liberty by evil-minded rulers. The greatest dangers to liberty lurk in insidious encroachment by men of zeal, well-meaning but without understanding.

Olmstead v. United States, 277 U.S. 438, 479 (1928) (Brandeis, J., dissenting) (footnote omitted).

124 Burkart Randall Div. of Textron, Inc. v. Marshall, 625 F.2d 1313, 1324 (7th Cir. 1980) (Sprecher, J.). Judge Sprecher also labelled the particularized probable cause requirement for complaint inspections "paradoxical." Id. at 1318 n.5. See also United States v. Consolidation Coal Co., 560 F.2d 214, 220 (6th Cir. 1977), vacated, 436 U.S. 942, reinstated, 579 F.2d 1011 (6th Cir. 1978), cert. denied, 439 U.S. 1069 (1979); Rothstein, supra note 17, at $91 \&$ n.178. Cf. See v. City of Seattle, 387 U.S. 541, 555 (1967) (Clark, J., dissenting) (individual inspections more important than area inspections).

${ }^{125}$ The anomaly "is merely a recognition of the notion inherent in the fourth amendment that the scope of a warrant shall be tailored to the showing of probable cause." Burkart Randall Div. of Textron, Inc. v. Marshall, 625 F.2d 1313, 1328 (7th Cir. 1980) (Wood, J., dissenting).

${ }^{128}$ Marshall v. Barlow's, Inc., 436 U.S. 307, 320 (1978). 
clause varies in proportion to the intrusiveness of the proposed search. ${ }^{127}$ Narrowing the scope of the potentially abusive and harassing complaint inspection is neither more nor less anomalous than allowing a programmed inspection to be broader than the highly intrusive criminal search.

4. The Proper Standard of Probable Cause. The proper level of probability necessary to justify a complaint inspection must be determined through the Camara balancing test. ${ }^{128}$ In degree of intrusiveness, the complaint inspection resembles a criminal search. ${ }^{129}$ Both involve nonroutine and hostile searches for evidence of a suspected violation, and both provide opportunities for harassment. Because the violations sought in the complaint inspection are not criminal, ${ }^{130}$ however, a less stringent showing of probability than that required for criminal searches is appropriate. ${ }^{131}$ The proper level of probable cause for complaint inspections

${ }^{327}$ See Marshall v. Horn Seed Co., 647 F.2d 96, 101 n.4 (10th Cir. 1981):

We believe the paradox is more seeming than real. The particularized inquiry is triggered by the need to limit the otherwise unrestricted discretion of OSHA officials, a concern which is not present when a search conforms to administrative or legislative guidelines. In the latter case, the plan itself severely restricts administrative discretion. Thus there is less need for judicial oversight.

See also text and notes at notes 69-73, 101-110 supra.

${ }^{128}$ See text and notes at notes 65-68 supra.

129 See Marshall v. Horn Seed Co., 647 F.2d 96, 101 n.4 (10th Cir. 1981) ("an administrative warrant application based on specific evidence is more analogous to an application for a criminal search warrant than to an application for a search warrant under a regulatory scheme").

130 OSHA generally imposes "civil" penalties that can range up to $\$ 10,000$. 29 U.S.C. $\S 666(a)-(d),(h)$ (1976). Arguments that these penalties "cross that elusive line between criminal fines . . . and civil regulatory sanctions" have been unsuccessful. Atlas Roofing Co. v. OSHRC, 518 F.2d 990, 994 (5th Cir. 1975), aff'd, 430 U.S. 442 (1977). See Atlas Roofing Co. v. OSHRC, 424 U.S. 964 (1976) (grant of certiorari) ("assuming arguendo" in agreeing to review the Fifth Circuit's decision, "that such civil penalties and enforcement procedures are civil in nature and effect"). The Supreme Court's jurisprudence in this area approaches complete deference to congressional labelling. See United States v. Ward, 448 U.S. 242 (1980); Atlas Roofing Co. v. OSHRC, 430 U.S. 442, 460 n.15 (1977). See generally Charney, The Need for Constitutional Protections for Defendants in Civil Penalty Cases, 59 CoRNELL L. REv. 478 (1974).

The Act does contain criminal penalties. 29 U.S.C. $§ 666(\mathrm{e})$-(g) (1976). Searches made to acquire evidence for such penalties must be supported by criminal probable cause. In re Metal Bank of Am., Inc., 9 Occ. Safety \& Health Cas. (BNA) 1972, 1974 (E.D. Pa. 1981) (dictum).

${ }^{131}$ The Supreme Court has stated that "[p]robable cause in the criminal law sense is not required" for OSHA searches. Marshall v. Barlow's, Inc., 436 U.S. 307, 320 (1978). Accord, Marshall v. Horn Seed Co., 647 F.2d 96, 99 n.2 (10th Cir. 1981); Burkart Randall Div. of Textron, Inc. v. Marshall, 625 F.2d 1313, 1317 (7th Cir. 1980); Weyerhaeuser Co. v. Marshall, 592 F.2d 373, 377 (7th Cir. 1979); In re Gilbert \& Bennett Mfg. Co., 589 F.2d 1335, 1338-39 (7th Cir. 1979); BP Oil, Inc.v. Marshall, 509 F. Supp. 803, 806 (E.D. Pa. 1981); West 
thus lies between that required for criminal searches and that provided by an administrative plan.

The Supreme Court has identified such a middle ground, labelled "reasonable belief," in its stop-and-frisk cases. ${ }^{132}$ This level of probable cause is endorsed by the Act itself, which requires that the Secretary inspect only if he has "reasonable grounds to believe" the alleged hazard exists. ${ }^{138}$ Under the reasonable belief standard, a warrant should issue if the employee's allegations are credible $^{134}$ and support a reasonable belief that the violation will be found in the place alleged. ${ }^{135}$

Point-Pepperell, Inc. v. Marshall, 496 F. Supp. 1178, 1182, 1184 n.7 (N.D. Ga. 1980); Marshall v. North Am. Car Co., 476 F. Supp. 698, 703 (M.D. Pa. 1979), aff'd, 626 F.2d 320 (3d Cir. 1980); Sarasota Concrete Co., 9 Occ. Safety \& Health Cas. (BNA) 1608, 1615 (OSHRC 1981); Comment, Administrative Roulette: Safety Inspection Probable Cause in Light of Marshall v. Barlow's, Inc., 23 St. Louis U.L.J. 768, 788 (1979). But see H. REP. No. 1765, 91st Cong., 2d Sess. 37, reprinted in 1970 U.S. CodE CoNG. \& AD. NEws 5228, 5234 (OSHA searches require "probable cause"); Comment, supra note 103, at 796; Note, Administrative Search Warrants, 58 Mins. L. Rev. 607, 639-41 (1974). Cf. In re Urick Property, 472 F. Supp. 1193, 1194-95 (W.D. Pa. 1979) (implying that criminal probable cause is required).

${ }^{132}$ See Terry v. Ohio, 392 U.S. 1 (1968); Greenberg, supra note 79, at 1015-16. Basing its decision on the Camara balancing test, 392 U.S. at 20-21, the Terry Court found a stopand-frisk reasonable where a police officer had reason to suspect that an individual was harboring a concealed weapon, but his suspicions did not rise to the level of criminal probable cause. See also United States v. Brignoni-Ponce, 422 U.S. 873, 881 (1975) (administrative border search); Almeida-Sanchez v. United States, 413 U.S. 266, 268 (1973) (same).

13329 U.S.C. \& 657(f)(1) (1976).

${ }^{234}$ Under the stop-and-frisk cases, the informant's information must carry "indicia of reliability" even though it need not meet the reliability test applied to criminal searches. See Adams v. Williams, 407 U.S. 143, 147 (1972); Greenberg, supra note 79, at 1015 n.26. On the requirement of "indicia of reliability" in the OSHA context, see note 95 supra. OSHA also should inform the magistrate of any indicia of unreliability, such as evidence that the complainant lied, e.g., Marshall v. North Am. Car Co., 476 F. Supp. 698, 701 (M.D. Pa. 1979) (complainant recently fired for falsifying medical report), aff'd, $626 \mathrm{~F} .2 \mathrm{~d} 320$ (3d Cir. 1980); or evidence of bad motive, e.g., BP Oil, Inc. v. Marshall, 509 F. Supp. 802, 804-05 (E.D. Pa. 1981) (complaint used by union for bargaining leverage during strike). See also Marshall v. Horn Seed Co., 647 F.2d 96, 103 (10th Cir. 1981) (OSHA need not always seek out information, but what it has it must reveal).

${ }^{135}$ The Tenth Circuit has attempted to formulate a standard of probable cause for complaint inspections that appears to be less stringent than the "reasonable belief" standard:

[T]o issue a warrant, the magistrate need not have a reasonable belief that a violation will be found. Nor need he even find it more probable than not that a violation will be uncovered .... When the warrant application is grounded not upon conformance with administrative or legislative guidelines but upon "specific evidence" of violations such as an employee complaint, there must be some plausible basis for believing that a violation is likely to be found.

Marshall v. Horn Seed Co., 647 F.2d 96, 102 (10th Cir. 1981) (emphasis in original). This standard is too close to the level of probability required of an administrative plan, and it does not sufficiently consider the hostility and potential for harassment of the complaint 
The search authorized must be limited to investigation of the alleged violations and any elements or manifestations thereof for which reasonable belief exists. ${ }^{136}$ Evidence of violations garnered outside of this limited scope should be excluded from penalty proceedings. ${ }^{137}$ Although establishment of an intermediate level of probability for complaint inspections further complicates administration of the warrant requirement, ${ }^{138}$ such variation is the inevitable result of applying a reasonableness standard to the warrant clause in administrative warrant cases. ${ }^{139}$

inspection. Numerous courts have employed the more stringent reasonable belief standard. See BP Oil, Inc. v. Marshall, 509 F. Supp. 802, 807 (E.D. Pa. 1981) ("reasonable grounds to believe that violations existed"); Marshall v. North Am. Car Co., 476 F. Supp. 698, 703 (M.D. Pa. 1979) ("inspection must be reasonable under all the circumstances"), aff'd, 626 F.2d 330 (3d Cir. 1980); In re Central Mine Equip. Co., 7 Occ. Safety \& Health Cas. (BNA) 1185, 1189-90 (E.D. Mo.), vacated on other grounds sub nom. Marshall v. Central Mine Equip. Co., 608 F.2d 719 (8th Cir. 1979). See also West Point-Pepperell, Inc. v. Marshall, 496 F. Supp. 1178, 1183 (N.D. Ga. 1980) ("at least a reasonable prospect . . . that the violations ... are occurring").

${ }^{136}$ See text and notes at notes 94-96 supra. In Terry v. Ohio, 392 U.S. 1, 18, 30 (1968), the Court approved a weapons search "carefully restricted . . . to what was appropriate to the discovery of the particular items . . . sought," but noted that "a search which is reasonable at its inception may violate the Fourth Amendment by virtue of its intolerable intensity and scope."

${ }^{137}$ The applicability of the exclusionary rule, which forbids the use of illegally seized evidence at trial, is "sharply contested" in the context of OSHA civil proceedings. Babcock \& Wilcox Co. v. Marshall, 610 F.2d 1128, 1139 \& n.41 (3d Cir. 1979). Compare Savina Home Indus., Inc. v. Secretary of Labor, 594 F.2d 1358, 1362-63 (10th Cir. 1979) (rule applies) with Todd Shipyards Corp. v. Secretary of Labor, 586 F.2d 683, 689 (9th Cir. 1978) (questioning the applicability of the rule). See also Trout, OSHA and the Exclusionary Rule: Should the Employer Go Free Because the Compliance Officer Has Blundered?, 1981 Duks L.J. 667; Note, The Applicability of the Exclusionary Rule in Administrative Adjudicatory Proceedings, 66 IowA L. REv. 343 (1981). The OSHRC has invoked the exclusionary rule where a complaint inspection exceeded its permissible scope. Sarasota Concrete Co., 9 Occ. Safety \& Health Cas. (BNA) 1608, 1612-15 (OSHRC 1981).

Because OSHA penalties are civil rather than criminal, see note 130 supra, the exclusionary rule's rationale might not extend to OSHA searches. As an alternative remedy, Congress could allow employers whose premises have been illegally searched to correct the illegally discovered violations without penalty.

${ }_{138}$ See Note, Rationalizing Administrative Searches, 77 Mich. L. REv. 1291, 1314 n.130 (1979).

130 See text and notes at notes 61-68, 86-91 supra. Dunaway v. New York, 442 U.S. 200, 213-14 (1979), suggests that the Supreme Court is not always willing to engage in rebalancing. In that case, however, the Court dealt with a situation that under settled law had been held to the traditional standard of probable cause. In contrast, an OSHA complaint inspection falls in an area already opened to rebalancing by Camara and See and is a type of search for which Michigan v. Tyler, 436 U.S. 499 (1978), indicates the Court's willingness to rebalance. 


\section{Conclusion}

This comment has demonstrated that wall-to-wall inspections cannot be based on specific employee complaints. The Secretary of Labor's statutory authority to conduct complaint inspections is limited to investigation of alleged violations and dangers. The scope of complaint inspections also is limited by the fourth amendment, because an employee complaint provides the requisite probable cause solely for those areas it directly implicates. Only when complaint inspections are thus limited can they pass statutory and constitutional muster.

George S. Leone 